NBER WORKING PAPER SERIES

THE INTRAFAMILY

ALLOCATION OF GOODS -

HOW TO SEPARATE THE

MEN FROM THE BOYS?

Reuben Gronau

Working Paper No. 1956

NATIONAL BUREAU OF ECONOMIC RESEARCH 1050 Massachusetts Avenue

Cambridge, MA 02138

June 1986

The research reported here is part of the NBER's research program in Labor Studies. Any opinions expressed are those of the author and not those of the National Bureau of Economic Research. 
Working Paper \#1956

June 1986

The Intrafamily Allocation of Goods - How to Separate the Men from the Boys?

\begin{abstract}
$\underline{\text { ABSTRACT }}$
The paper integrates the basic principles of consumption theory and the economics of human resources to generate adistribution of consumption between parents and children. Invoking the assumption of separability between parents' and children' consumption and the corresponding assumption of two-stage budgeting, it is shown that one can estimate the parents' share in total consumption by snalyzing the effect of demographic changes on the consumption of aduit goods (1.e. "gooda consumed exclusively by parents).

Using the U.S. $1972 / 73$ Consumption Expenditure Survey it is found that white married families tend to allocate about three-quarters of their consumption to parents and one quarter to children. The children's share of consumption in black families does not fall short of those in white families, and the ahare in white families where the father is absent is even higher. The share increases with the number of children, iut the absolute level of consumption per child declines. These findings are quite robust to changes in functional form and data-base.
\end{abstract}

Reuben Gronau

Department of Economics

Hebrew University

Mt. Scopus, 91905

Jerusalem ISRAEL 


\section{The Intrafamily Allocation of Goods - How to Separate the Men from the Boys?}

\section{Introduction}

The intrafamily allocation of resources has long intrigued economists of diverse interests: human-resources economists interested in investment in children, economic demographers interested in the cost of children, theorists interested in intergenerational transfers, econometricians measuring the effect of demographic variables on consumption, and those (macro, development, public finance and consumption economists) interested in adult equivalence scales. Common to them all is the recognition of the important ramifications of the distribution of resources between parents and children, husband and wife, to fertility patterns, marital stability, capital accumulation, growth rates, income distribution and even to the efficacy of macro-economic policy.

If so little is still known about this aspect of household behavior it is not for lack of trying. Direct and indirect estimates of intrafamily allocation date back to Engel's estimates of adult equivalence scales (1895). The major obstacle to empirical research in this field is the lack of direct evidence. Very few expenditure items are assigned to specific household members, and consumption is generally reported on a household level with no way of assigning portions of it to individual household members without additional assumptions. Disagreement on the nature of these assumptions has prevented empiricists from reaching a consensus.

Past studies adopted one of two approaches: economic demographers trying to measure the cost of children were guided by the theory of fertility, while those interested in aduIt equivalence scales used the theory of consumption as 
their point of departure. Cross-fertilization is still quite rare. This paper enlists the principles of both consumption theory and the economics of human resources to establish a common ground for the imputation of the intrafamily allocation of resources.

The present analysis reveals that in the absence of direct infomation the imputation of the distribution of goods between parents and children requires the assumption that parents' preferences for their own consumption are unaffected by the existence of children and by the composition of children's consumption. The assumption of separability between parents' and children's consumption (and the corresponding assumption of two-stage budgeting) serves as a base for estimation, where the observed effect of demographic variables on goods consumed exclusively by parents (adult goods) is used as an indicator of their effect on parent's overall consumption.

A preliminary discussion of the nature of the problems faced by the empirical researcher lays the groundwork for the formal model. Separability between parents' and children's consumption and the distinction between preferences and home technology are the cornerstones for the estimation procedure. Preliminary estimates based on the U.S. 1972 Consumption Expenditure Survey and allowing for a linear distribution rule indicate that white married families tend to allocate about three-quarters of their consumption to parents and one-quarter to children. Further investigation reveals that the finding is quite robust to changes in population, in functional form, and in data-base.

II. Preliminary Discussion - Master and Siaves

The imputation of the intrafamily allocation of resources implicit in the 
estimation of both adult equivalence scales and the cost of children is beset with controversy. ${ }^{1}$ The controversy focuses on two central questions: how to estimate the distribution within the household and what is actually estimated. An increase in family size is associated with an increase in household consumption. The incremental consumption, however, understates the resources diverted to children as it does not account for cuts in parents' own consumption. One source of controversy is what feature of consumption (e.g., the consumption of which good) can serve as an indicator of these cuts. A second cause of confusion is the tendency to overemphasize consumption technology.

Economists are reluctant to distinguish between "needs" and "wants". One of the few exceptions is the case of adult equivalence scales, which are often defined as "needs-corrected" deflators of income. These scales purport to reflect changes in the family's needs as it expands or as its memeber grow older, as well as returns to scale in consumption. In a different context (the economics of fertility) a distinction is made between the number of children and their "quality". The decision whether to have more children or invest more in every child depends on the fixed costs of children and on the cost of increasing the child's "quality" (Becker and Lewis, 1973). Given that parents' decisions are affected by home production technology (i.e. children's needs, fixed costs, and economies of scales) as well as by preferences, the question arises whether one can identify and estimate the parameters of home technology. To clear up the confusion it is convenient to move away from the family context. Borrowing a page from cleometrics, let us assume two kinds of farms: an owner-run farm and a farm using slave-labor. Comparing the consumption levels of these two kinds of farms, and noting that consumption levels are about the same, it would be hard to conclude that slaves" "needs" are substantially lower 
than those of the master, or that the consumption function demonstrates sharply increasing returns to scale. Rather, most observers will interpret the findings in terms of the "master" caring for his slave. To study the slaves" "needs" and returns to scale we require separate ledgers for the farmhouse and the mansion. Given separate information on the slaves' consumption we may be able to deduce the returns to scale from information on changes in consumption levels as the number of slaves changes. To study differences in "requirements," we have to compare the consumption levels of slaves of different ages and sexes. There is no way these findings can be used to compare "slave needs" with those of "masters." In either case the researchers will be careful to isolate from the slave's expenses those components which are fixed (e.g., the price paid for the slave).

Measuring home production technology becomes more complicated when the plantation does not maintain separate accounts for "slaves" and "masters." A prerequisite for estimation is the assumption that the master's "tastes" are not changed by the existence and number of slaves. He may change his consumption patterns because changes in the number of slaves are associated with a change in income or relative prices (e.g., the price of home services), but this does not affect his consumption function. Put differently, one has to assume that the utility the master derives from his own consumption and from that of his slaves are separable. The assumption of "separability" is crucial for any imputation of the distribution of resources on the farm.

To isolate the consumption of farm owners from the consumption of the rest of the work force, there must be some goods which are consumed exclusively by the owner. The comparison of consumption patterns of these goods in farms of different sizes is indicative of the change in prices and budgets facing the mansion's housekeeper. This comparison should (under certain conditions) allow 
us to decipher the allocation problem: how much of the total farm budget is consumed by the owners and how much by the slaves.

Returning to the estimation of intrafamily allocation, the most disturbing part of the analogy is the assumption of separability. Most household consumption decisions rest with the parents. Their decision how to allocate the budget between their own consumption and that of their children depends on how the two kinds of consumption enhance the parents' welfare. Whereas it is easy for the researcher to accept the assumption of separability when it comes to masters and slaves, it is somewhat less acceptable in the case of parents and children. Quoting Samuelson (1956, p. 9), "Where the family is concerned the phenomenon of altruism inevitalbe raises its head: if we can speak at all of the indifference curves of any one member, we must admit that his tastes and marginal rates of substitution are contaminated by the goods that other members consume. These Veblen-Duesenberry external consumption effects are the essence of family Iife".

The natural excuse for adopting the assumption of separability in the family context is provided by Samuelson himself - it is a prerequisite for defining a family demand structure endowed with all "the nice properties of modern consumption theory." This becomes especially important when one compares the consumption pattern of childless families with those of families with children, where it is assumed that both have the same "tastes".

Nonetheless, it is worth investigating the assumption of separability to learn how unacceptable it really is. Separability does not rule out altruism. It does not even rule out parents' care for what their children consume. What it does rule out is parents' preferences for their own consumption being affected by their children's consumption composition. Thus, it rules out the case where parents' enjoyment from $T V$, music or travel is affected by the 
attendance of their children. It also rules out the case that parents change their consumption habits to set a personal example for their children.

The link between the composition of parents' and children's consumption may not be a direct one. Family goods (i.e., family "public good") may serve as a link between parents' and children's private goods. Thus even if the utilities parents derive from their own and from their children's consumption are separable, parents' and children's consumption of private goods are not, if they are affected by the composition of family goods.

An alternative indirect link is indivisibilities and returns to scale in home production. Parents may adapt their consumption habits to those of their children not because of interacting preferences but because of "economies of scale due to sharing" in home production. Thus, a family that is observed ordering five different menues at a restaurant will share the same meal at home. Mothers and their teenage daughters are often observed to share the same wardrobe.

Children may affect the shadow prices facing their parents in other ways. They are known to raise their mothers' shadow price of time, and thus raise the price of time-intensive activities. Somethimes they even increase the pecuniary costs of some activities (e.g., the cost of out-of-home entertainment is increased when one has to pay for babysitting).2

Granting the existence of interaction between parents' and children's consumption it is not clear how important this interaction is empirically (one test of the assumption of separability is provided in section VI). It seems, however, that ignoring this interaction and its sources is standard procedure in consumption and demand analysis. The assumption of separability of private and public goods is implicit in most studies of the demand for private goods. 
Indivisibilities and excess capacity in housing or home appliances have not impared the study of demand for these durable goods. Increasing returns to scale can often be construed as declining incremental fixed costs of children and incorporated in the analysis. The shadow price of time and its effect on the allocation of goods is usually ignored in consumption studies. By assuming separability this study does not set a precedent and is in line with standard procedure.

Bearing these resevations in mind, we stick with the analogy of the farm and the family. The separation of parents' consumption from that of their children is a necessary condition for the study of consumption technology (returns to scale and children's "needs"), and there is no way of comparing children's needs with those of parents (i.e., adults) unless we assume that parents love their children as much as they love themselves (i.e., that children's consumption yields the same utility as their own consumption). Finally, the key to the distribution problem lies in the comparison of consumption patterns of "adult goods" between families with and without children.

\section{The Model - Separating the Men from the Boys}

The framework of the analysis is a one-period model. The parents' utility function has two components - the utility derived from their own consumption $\left(U^{A}\right)$ and the utility derived from their children's consumption ( $U^{B}$ ). The utility function is (weakly) separable in the two components$$
\mathrm{U}=\mathrm{U}\left(\mathrm{U}^{\mathrm{A}}, \mathrm{u}^{\mathrm{B}}\right)
$$ 
In turn, $\mathrm{U}^{\mathrm{A}}$ depends on the quantity of goods consumed by parents, $\mathrm{q}_{i}^{\mathrm{A}}$,

$$
u^{A}=U^{A}\left(q_{1}^{A}, \ldots, q_{n}^{A}\right)
$$

where $q_{n}^{A}$ denotes adult goods - goods consumed exclusively by parents. ${ }^{3}$ The utility generated by the children's consumption depends on the specific basket consumed $\left(q_{i}^{B}\right)$ and on what parents regard as children needs $\left(\rho_{i}\right)$

$$
u^{B}=v^{B}\left[\left(q_{1}^{B} / \rho_{1}\right), \ldots \ldots\left(q_{n-1}^{B} / \rho_{n-1}\right) ; K\right],
$$

where $K$ denotes the number of children. The coefficients $\rho_{i}<1$ if parents regard children's needs to be lower than their own (e.g., if children's nutxitional requirements are lower than those of adults, the same amount of food will produce higher nutritional values for children than for adults)." The utility function ( 1 ) is maximized subject to the budget constraint

(4) $\quad \sum_{i=1}^{n} \quad p_{i} q_{i}=x-C(K)$,

where $q_{i}=q_{i}^{A}+q_{i}^{B}$, $x$ denotes income, and children involve fixed costs of $C$. These costs may be associated with the birth of the child, or, more often, with some minimum subsistence expenditures which assure the children's survival. 5 The difference between "needs" $\left(\rho_{i}\right)$ and minimum requirements, of ten blurred in the existing literature, is an important feature of the model. The budget constraint implicitly assumes a fixed supply of labor and constant returns to scale in consumption. ${ }^{8}$

The conditions for an optimum look familiar

$$
\begin{aligned}
& u_{i}^{A}=\lambda p_{i} \\
& u_{i}^{B}=\lambda \rho_{i} p_{i}
\end{aligned}
$$


where $u_{i}^{j}=\partial U / \partial q_{i}$, and $\lambda$ denotes the marginal utility of income. The optimum conditions underline two important points:

a. In this formulation, differences in children's "needs" ( $\rho_{i}$ ) play a role similar to variability in prices.

b. The optimum allocation is affected by children's "needs," but no less important is the weight placed by parents on their own consumption relative to that of their children ( $u_{i}^{A}$ and $u_{i}^{B}$, respectively).

Whereas the first point may remind one of Gorman's and Barten's analysis, suggesting that one can derive the values of $\rho_{i}$ and compare them with adult "needs," the second point comes to forewarn that there is no way to infer relative "needs" by comparing parents' and children's consumption (i.e., comparing across equations) unless one is ready to assume that the weights given to them in the parents' welfare function are the same $\left(u_{i}^{A}=u_{i}^{B}\right)$.

To derive the comparative statics properties of the model one has to invoke the separability assumption and the corresponding assumption of two-stage budgeting (Deaton \& Muellbauer, 1980, Ch. 5). 8 By that assumption the allocation decision is made in two stages: in the first stage the parents decide how to allocate total consumption between their own ( $X^{A}$ ) and their children's $\left(\mathrm{x}^{\mathrm{B}}\right)$, where

$$
x^{A}+x^{B}=x-C(K)
$$

In the second stage they decide how to allocate each budget $x^{j}$ between different goods, where

$$
\Sigma \quad P_{i}^{n} a_{i}^{j}=x^{j} \quad i=1
$$

The study of intrafamily allocation focuses primarily on the first stage, trying to estimate the distribution rule 


$$
x^{A}=h(x, p, \rho, C ; K)
$$

Parents' consumption $x^{A}$ is expected to increase with total family consumption, and, consequently, to decline when the cost of children increases. The effect of a change in one of the prices $p_{i}$ depends on the share of the good in parents' and children's consumption, and on the price elasticity of $x^{A}$. For example, an increase in food prices may increase the relative price of children's consumption if food constitutes a greater share in the consumption of children than in that of parents'. This price increase raises children's consumption if it is price inelastic. An increase in children's needs $\left(\rho_{i}\right)$ plays a role similar to a price increase, and will result in an increase of children's consumption at the expense of parents' only if the price elasticity of $\mathrm{X}^{\mathrm{B}}$ is less than unity. Returns to scale in consumption involve an income effect, but may also involve a price effect if the scale economies have a different effect on different consumption acitivities and if the compositions of $\mathrm{X}^{\mathrm{A}}$ and $\mathrm{X}^{\mathrm{B}}$ differ.

\section{Estimation}

The family's demand for any specific good depends on the separate demand of parents and children for that good, and on the distribution of resources within the family. Two-stage budgeting implies

$$
\text { (9) } \quad q_{i}^{A}=g_{i}^{A}\left(x^{A}, p\right) \text { and } q_{i}^{B}=g_{i}^{B}\left(x^{B}, \rho p\right) \text {. }
$$

Hence,

$$
q_{i}=q_{i}^{A}+q_{i}^{B}=g_{i}^{A}[h(), p]+g_{i}^{B}[x-h(), \rho p],
$$


where $h()$ is the distribution rule. In general, therefore, there is no way of separating the specific elements of demand $g_{i}^{j}()$ from the distribution rule. Separability allows the estimation of the parents' demand $g_{i}()$ from a sample of childless families (i.e., where $x^{A}=x$ ). The identification of $h($ ) from equation (10) requires that $g_{i}^{B}()=0$. In this case, the case of the adult goods, the demand of families with children can be rewritten

$$
q_{n}=g_{n}^{A}[h(), p],
$$

and one can identify $h\left(\right.$ ) as long as $g_{n}^{A}$ is a monotonic function of $x^{A}$. 9 For example, let $g_{n}$ and $h$ be linear

$$
q_{n}=\alpha_{0}+\alpha_{1} s+\alpha_{2} x^{A}
$$

and

$$
x_{A}=\beta_{0}+\beta_{1} s+\beta_{2}(x-C)+\beta_{3} \rho,
$$

where $S$ is a set of environmental variables (e.g., age, race, schooling), and where prices (p) are omitted in cross section estimates.10 The demand for adult goods by families with children therefore equals

$$
{ }_{n}=\left[\alpha_{0}+\alpha_{2}\left(\beta_{0}-\beta_{2} C\right)\right]+\left(\alpha_{1}+\alpha_{2} \beta_{1}\right) s+\alpha_{2} \beta_{2} X+\alpha_{2} \beta_{3} \rho .
$$

The parameters $\alpha_{i}$ can be estimated from a sample of families without children. Comparing these estimates with the estimates derived from a sample of families with children [i.e., comparing equations (12) and (14)], one can generate the estimates of $\beta_{i}$ - the parameters of the distribution rule [equation (13)]. Specifically, comparing the marginal propensities to consume adult goods $\left(\alpha_{2}\right.$ and $\left.\alpha_{2} \beta_{2}\right)$ generates the estimate of the marginal propensity 
of adult consumption $\beta_{2} \cdot$ Given $\alpha_{1}$ and $\alpha_{2}$ one can estimate the effect of the environmental variables $\left(\beta_{1}\right)$ on $x^{A}$. There is, however, no way of separating the fixed costs (C) from the fixed component in the distribution equation $\left(\beta_{0}\right)$. To estimate the fixed costs one has to make additional assumptions about the fixed component (e.g., that $\beta_{0}=0$, or that it does not change with the number of children).

Children's needs ( $\rho$ ) are supposed to change with their age. The change in needs affects parents' consumption if its price elasticity differs from unity. Unfortunately, one cannot tell from observing the effect of children's age on the demand for adult goods by how much children's needs change with their age, without independent information on the price elasticity of $x^{A}$ (i.e., one cannot separate $\beta_{3}$ from $\rho$ ).

Similar methods can be used to identify the parameters $\beta_{i}$ if $g_{n}^{A}$ and $h$ are of a higher polynomial order, as long as $g_{n}^{A}$ is confined to the range where $\partial q_{n} / \partial x^{A}>0$. It is worth noting, however, that if the distribution rule $h$ is linear, the demand for adult goods in families with and without children will be of the same polynomial order.

\section{Preliminary Results: Three to One}

Our data consist of a subsample of the U.S. 1972/73 Consumer Expenditure Survey.11 The household's decision process may change with the number of adults in the household.12 To isolate this factor $I$ focused on families with husband and wife present. The sample consists of white families with less than four children. Since the key identifying variable is defined as clothing of adults age sixteen or older, I excluded from the sample families with children older 
than fifteen. The sample contains 7,793 observations, and the sample means are presented in Table 1 .

The identifying variables in this scheme are the group of adult goods. Traditionally, this group consists of three goods: adult clothing, tobacco, and alcoholic beverages. The analysis of the demand of the last two goods has always been regarded as problematic (because of response errors and a low MPC) (Alkinson, Gomulka, Stern, 1984a,b). We therefore used two versions of $q_{n}$ : adult clothing, and adult goods, where the latter measurese expenditures on all three goods combined. ${ }^{3}$ The list of environmental variables contains the husband's education, his age (and the square of this term), his employment status and that of his wife (or alternatively, the number of weeks they worked), region of residence (North-Central, South, and West), and whether the family lives in a rural area.

Running the regression for adult clothing separately in each of the samples defined by the number of children (Table Al in the appendix) confirms our expectations - there is a substantial decline in the marginal propensity to consume adult clothing as the number of children increases.

Since most of the environmental variables proved to be statistically insignificant they were omitted from the following regressions. The only variables kept are the husband's schooling (which is shown to have a positive effect) and the number of weeks the wife worked (employed women spend more on clothing). Of special interest among the omitted variables is the age composition of children (i.e., the number of children in the age group 2-15), which proves insignificant, regardiess of the number of children.

The regressions with the reduced set of variables were reestimated in the combined sample, with a dummy variable $(K)$, denoting the existence of children, 
to allow for differences in slopes and intercepts between the samples. The estimating equation is

$$
q_{n}=a_{0}+a_{1} s+a_{2} X+a_{3} k+a_{4} k s+a_{5} k X
$$

where $S$ denotes the control variables. Comparing (15) with (12) and (14) $a_{0}=\operatorname{est}\left(\alpha_{0}\right), \quad a_{1}=\operatorname{est}\left(\alpha_{1}\right), \quad a_{2}=\operatorname{est}\left(\alpha_{2}\right), a_{3}=\operatorname{est}\left[\alpha_{2}\left(\beta_{0}-\beta_{2} C\right)\right]$, $a_{4}=\operatorname{est}\left(\alpha_{2} \beta_{1}\right), \quad a_{5}=\operatorname{est}\left(\alpha_{2}\left(\beta_{2}-1\right)\right) \cdot$ Hence

$$
\begin{aligned}
& \operatorname{est}\left(\beta_{2}\right)=1+\left(a_{5} / a_{2}\right) \\
& \operatorname{est}\left(\beta_{1}\right)=a_{4} / a_{2}, \\
& \operatorname{est}\left(\beta_{2} c-\beta_{0}\right)=-a_{3} / a_{2} .
\end{aligned}
$$

The regressions presented in Table 2 are most illuminating. The existence of children reduces the marginal propensity to consume adult clothing by a quarter. Put differently, on average, the marginal propensity of parents' consumption is 0.76 , while that of children is 0.24 . The distribution of family consumption between parents' consumption and that of children is not affected by the husband's education, but is affected by the wife's employment status.14 The more the wife works (consumption held constant) the more pecuniary resources are diverted from parents' to children's consumption. This may be indicative either of the increased fixed costs of children associated with the mother's work (e.g., childcare services), or of an attempt to compensate children for smaller time inputs of working mothers.

An increase in the number of children may increase both the fixed costs associated with children and the children's share in consumption. Assuming that the fixed component in the distribution rule ( $\left.\beta_{0}\right)$ is unaffected by the number of children, an increase in fixed costs is expected to reduce the constant term 
in the consumption function for adult goods, whereas an increase in the children's share will reduce the marginal propensity to consume.

The separate regressions presented in Table AI indicate that as the number of children increases the marginal propensity to consume declines slightly but the constant term increases (in algebraic value). To test the significance of this result I added two variables to equation (15) denoting the existence of 2 and 3 children $\left(K_{2}\right.$ and $K_{3}$, respectively), and their interaction with consumption. 15 The expanded regression [equation (2) in Table 3] confirms the earlier findings - the MPC of adult clothing declines with the number of children. The implied marginal propensities of children's consumption are $0.20,0.22$, and 0.27 for families of 1,2 , and 3 children, respectively. Additional children are also accompanied by a decline in the constant term, but whereas the difference in the MPC adult clothing between families with no children and families with one child is highly significant, all the new variables are not. A comparison of the explanatory power $\left(R^{2}\right)$ of the new regression with that of the earlier ones [equation (4) in Table 2] indicates that although each of the new variables is not statistically significant, the four as a group are. These seemingly contradictory results are traced to the high correlation between $k_{i}$ and the interaction term $k_{i} X$ (the correlation coefficient for both $k_{i}$ is 0.9). Reestimating the equation with $K_{i}$, leaving out the interaction terms [equation (3) in Table 3], and estimating it with the interaction terms but without $k_{i}$ [equation (4)], shows that there is no advantage to one form over the other. By the first equation, the fixed cost per child (beyond the first) seems to be constant, while the second equation indicates that the incremental share in consumption is fixed (about 7 percent per additional child). Thus, additional children do increase the resources diverted to children, but muiticollinearity prevents us from telling whether this is due to an increase in 
fixed costs or in the marginal propensity of children's consumption.

The environmental variables exhibit a similar pattern. For example, the family of a working wife sharply reduces its expenditures on adult clothing when it has a child (working mothers do not spend more on clothing than non-working mothers), but their expenditures are only slightly reduced when it has additional children.

Additional support for our conclusions is gained by estimating the regressions for adult goods (i.e., the expenditures on tobacco, alcoholic beverages, and adult clothing combined). ${ }^{16}$ The separate regressions (presented in Table A2 of the appendix) again demonstrate the negative relationship between the marginal propensity to consume adult goods and the number of children, and the fact that the children's age composition has no effect on these expenditures. Since children's age and the regional variables did not seem to affect the consumption of adult goods they were omitted from the following regressions. Reestimating the equations in the pooled sample (with dummy variables for children) sheds some new light on the role of the environmental variables on the allocation of resources between parents and children (Table 4).

Families where the mother is employed reduce expenditures on adult goods when they have children, as do the more educated and the older. The share of children's consumption seems to increase not only with the mother's employment but also with the husband's age and education. The decline in the MPC is, however, Identical to that reported in Table 2 ( 24 percent). For every three additional dollars parents spend on themselves, they spend one on their children. 


\section{Robustness}

Though the similarity of the results for adult clothing and adult goods is encouraging, it may still seem an odd feature of the demand for clothing that has nothing to do with intrafamily allocation. To dispel these doubts, the findings are subjected to a battery of tests:

a. The findings reported in the last section relate to white married families. The regression are reestimated for blacks.

b. If married families divert 25 percent of their resources to children, the not-married should divert a higher share. Thus, comparing the marginal propensities to consume adult goods between childless families and families with children, the decline should be sharper in the case of the not-married.

c. Naturally there is a substantial difference in the age structure of families with and without children (see Table 1). To isolate the age effect

I reestimated the results in a sample where the husband's age is under 50.

d. How crucial is the assumption of linearity for the estimates? To answer this question I estimated the regression using higher polynomial orders.

e. To ascertain that the findings do not merely reflect some oddity in clothing habits of the early 1970s, the regressions are reestimated for the $1960 / 61$ Consumer Expenditure Survey.

f. Separability of adult and child consumption implies that the marginal propensity to consume should be affected by the existence of children in the same way for all adult goods. The similarity of the results for adult clothing and adult goods is consistent with this prediction. An additional test is the comparison of consumption patterns of male and female clothing, tobacco, and alcoholic beverages.1?

Table 5 incorporates the results of the first four tests. Comparing the results of Table 2 with the first column in Table 5, there are hardly any 
differences in the consumption patterns of adult clothing between white and black married families. The decline in the marginal propensity to consume associated with children is almost identical (27 percent for blacks vs. 24 percent for whites). The only observable difference is the effect of the wife's labor force participation. Families of black working women tend to cut their expenditures on clothing when they have children (presumably because they divert more resources to their children), but this cut is not statistically significant. There is a sharp difference in the age structure of not-married white women who have children and those families with no children in the household (the average ages are 33 and 60 , respectively). To control for the age effect the sample of the not-married was confined to those under 50 years of age. The resuits confirm the expectations that the not-married divert a larger fraction of their resources to children. The decline in the marginal propensity to consume exceeds 60 percent.

If husband and wife share their consumption equally, and if there are no returns to scale in consumption, a 75:25 distribution of resources in married families would imply a distribution of $37.5: 25$ in families where the mother is not married. In this case the decline in the marginal propensity to consume is expected to be about 40 percent $(=25 / 62.5)$. The observed sharper decline (though it is not clear whether it is statistically significant) implies either that wives' share is less than one half, or that the not-married tend to cut their own share in favor of children. Note that when an additional dummy variable denoting the existence of two or more children is added to the regression, the marginal propensity to consume declines by about 40 percent when the mother has one child and by another 20 percent when she has two or more children.18

Confining the sample of white married families to those in which the head is less than 50 years old does not change the results considerably. The decline in 
the marginal propensity to consume adult clothing associated with children is somewhat lower than our earlier results, but the differences do not seem to be statistically significant.

The last two columns in Table 5 report the findings of a quadratic expenditure function. Let the demand for adult goods be a quadratic function of adult consumption

$$
q_{n}=\alpha_{0}+\alpha_{1} x^{A}+\alpha_{2}\left(x^{A}\right)^{2}
$$

and the distribution rule be linear

$$
x^{A}=\beta_{0}+\beta_{1}(x-C),
$$

then the demand of families with children equals

$$
\begin{aligned}
q_{n}=\left[\alpha_{0}+\right. & \left.\alpha_{1}\left(\beta_{0}-\beta_{1} c\right)+\alpha_{2}\left(\beta_{0}-\beta_{1} c\right)^{2}\right] \\
& +\left[\alpha_{1} \beta_{1}+2 \alpha_{2} \beta_{1}\left(\beta_{0}-\beta_{1} c\right)\right] x+\alpha_{2} \beta_{1}^{2} x^{2}
\end{aligned}
$$

where the effects of the environmental variables and of chidren's "needs" are incorporated, for simplicity of presentation, in the constant terms ( $\alpha_{0}$ and $\beta_{0}$ ). To estimate the marginal propensity of adult consumption one has to compare the coefficients of the quadratic term $\left(x^{2}\right)$ in families with and without children. ${ }^{19}$ The results reported in Table 5 imply a marginal propensity that is almost identical to the one reported earlier $\left(\hat{\beta}_{1}=0.73\right)$. We assume throughout this empirical section that the distribution rule h is linear in consumption (X). If $h$ is of a higher polynomial order, the consumption function of adult goods in families with children are of a higher polynomial order than that of families without children. The examination of higher polynomial regressions does not support this prediction. 
The results for adult goods are almost identical to those of adult clothing and hence are not reported here. 20

Our $1960 / 61$ sample contained close to 5,500 observations. The white families included in the $1960 / 61$ sample are somewhat older than those in the $1972 / 73$ sample. Given the high age of husbands in families without children, the sample was confined to families whose head was less than 65 years old.2i As in 1972/73, the sample consists of white families, husband and wife present, with less than four children. Since in this sample adult clothing refers to those age 18 years or more I excluded from the sample families with children or other relatives over 18 . The sample means are reported in Table 6.22

Repeating the earlier procedures and running the regression for adult clothing separately in each of the samples defined by the number of children (Table $A 3$ in the appendix), the result almost replicates those of the earlier experiment. Rerunning the regression in the pooled sample (Table 7) and comparing the results with those of $1972 / 73$ (Table 2) indicates that though clothing consumption patterns may have changed over the decade (the effect of the environmental variables differs, and the marginal propensity to consume is significantly higher) one feature remains constant - the marginal propensity to consume adult clothing declines by 25 percent when the family has children.23

The addition of $k_{2}$ and $K_{3}$ and their interactions does not help in dispelling the ambiguity concerning the effect of the number of children on the intrafamily allocation of resources. The results reported in Table 7 are contradictory: whereas a second child increases the marginal propensity of children's consumption by 14 percent (from 16 to 30 percent), three children (compared to one) contribute only to fixed costs but do not affect the marginal propensity to consume. This irregularity is hard to accept and should be attributed to the vagaries of multicollinearity (the correlation coefficients between $k_{i}$ and their interaction terms are 0.9 ). 
The findings relating to the black married and to white not-married families (Table 7), and the regression for adult goods (Tables 8 and A4 in the appendix) all contribute to consolidate the earlier evidence: the reduction in the MPC of blacks associated with children is $12-20$ percent ${ }^{4}$ and the not-married cut their MPC by more than the married (by 37 percent). The results for adult goods almost replicate those for adult clothing (though clothing constitutes less than two thirds of adult goods).

Finally, to test the assumption of separability I estimated in the $1972 / 73$ sample the consumption functions of male clothing, female clothing, tobacco, and alcoholic beverages separately. To test the hypothesis that the MPC of these goods declines by 25 percent when the family has childen I introduced a variable for "parents' consumption" into the regression. This variable is defined to equal family consumption in childless families and to equal 75 percent of consumption in families with children. If the assumption of separability holds, the coefficients of the interaction term "consumption $\times K$ " should turn statistically insignificant. As Table 9 indicates, all four adult goods pass this test successfully. In spite of the inherent differences in the consumption behavior (and specifically in the MPC) between these goods, in none of the cases can we reject the assumption that parents relate, in their decisions concerning their own consumption, to a budget that is 75 percent of the total consumption budget.

\section{Selectivity Bias}

The discussion in the preceding sections follows traditional demand analysis in assuming that children are exogenously given. This assumption naturally raises cries of "selectivity bias" - families with children may differ inherently from 
familes without children, thus giving rise to a self-selection bias.

How dangerous is such a bias? To answer this question one has to answer two separate questions: (a) does "having children" necessarily imply a greater tendency to spend on children?, (b) if such a tendency exists, does it affect our estimation procedure? In answering the first of these questions, the distinction has to be made between ex-ante and ex-post. A family with children, of course, spends ex-post less on parents than a family without children. But the relevant question is whether ex-ante a greater tendency to have children is associated with a distribution rule that favors children.

A greater tendency toward having children may result either from increased "tastes" for children or from a lower "price" of children. An increase in the weight parents assign to the welfare they derive from children ( $U U / \partial U^{B}$ ) $1 e a d s$, in general, to an increase in the children's budget $x^{B}$ at the expense of parents. But this is not necessarily true in the case of a lower "price". The parents' tendency to have children increases the lower their fixed costs. But lower fixed costs of children are associated with an increase in the parents' budget. The tendency may also increase with the "efficiency" of home production in that sector - i.e., the lower the value of $\rho$. But a lower value of $\rho$ results in an increase in the children's budget only if the elasticity of substitution between parents' and children's utilities exceeds unity.

Thus, ex-ante it is not clear that a greater tendency to have children implies a greater tendency to spend on children. Furthermore, even if such an association exists, it should not disturb the study of the intrafamily allocation of resources. What should disturb such a study is an association between the "taste" for children and the "taste" for adult goods - e.g., if adults who dislike children are fond of clothes. More specifically, our procedure is subject to selectivity biases only if adults who like children have a lower MPC of adult 
goods. Finally one has to recall that our procedure is based on the comparison of families with children and families without children at home. The latter are much older than the former, and most of them have grown-up offsprings who have already left home. Thus, the danger of a selectivity bias seems minimal.

To test for the existence of a selectivity bias we have to examine the effect of the "taste" for children on the MPC of adult goods. Conducting this test in the sample of families without children should indicate whether the bias exists. Conducting it in the sample of families with children should indicate the extent to which the "taste" for children is associated with increased spending on children.

A detailed test is beyond the scope of this paper. The test suggested here is, therefore, admittedly crude. To obtain a measure of the "taste" for children I estimate the probability that the family has children. The greater the deviation from this estimate (in algebraic value) the greater the "taste" for children. Thus, if the family has a child, the lower the predicted probability, the greater the importance of unobserved variables (i.e., "taste") in explaining the existence of children. Similarly, if the family has no children, the greater the predicted probability of children (the smaller the residual) the smaller the taste for children (the greater the "distaste"). Thus, the residual from this regression can be used to trace the existence of selectivity biases in our estimates of the demand for adult goods.

For obvious reasons I confined the sample to white married families where the wife is no older than 40 . To estimate the probability of having children I used a logit function. The dependent variable is $\mathrm{K}$ - the existence of children at home, and the explanatory variables consist of the wife's age (AGE), the husband's schooling ( $S C L$ ), the family's income (wife's earnings excluded - INCOME), and the regional variables. 25 
The logit estimates are

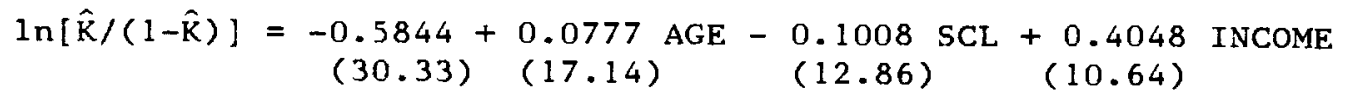

$$
\begin{aligned}
& +0.1169 \text { RURAL }-0.0112 \mathrm{NC}+0.0311 \text { WEST }-0.0108 \text { SOUTH } \\
& \begin{array}{llll}
(2.09)(0.19) & (0.51) & (0.19)
\end{array}
\end{aligned}
$$

where the values in parentheses are "t-values".

Defining the residual $e=k-\hat{k}$, the residual was incorporated in the regression of adult clothing (e is used as an independent variable and interacting with consumption). The results for the sample of families without children are reported in Table 10, and those for families with children in Table 11

The results are quite conclusive. Whereas e has no significant effect on the demand for adult clothing when the family has no children, it has a significant negative effect on the MPC of adult clothing when the family has children. Thus, a greater "taste" for children (a greater value of e) is not reflected in a smaller taste for adult clothing. It leads, however, to a greater tendency by parents to cut their own budget in favor of their children. In spite of its crudeness the test confirms our expectation that if a selectivity bias exists the effect is quite smal1.25 
VIII. The "Cost" of Children

The "cost" of children has recently been the focus of much attention of both economists and demographers (Espenshade, 1984; Lazear and Michael, 1985; Turchi, 1983). In a way, as some of these researchers recognize, the "cost" of children in a misnomer. Parents spend more on their children (i.e., invest more in their children) in the hope of improving the children's (and their own) present and future welfare. The recognition that higher expenditures lead to a higher "quality" of children is an integral part of the economics of fertility. Given this variation in quality, it is expenditures on children, or children's consumption, in which we are interested.

The estimates of children's consumption can be derived directly from the estimates of the distribution $h(X, S)$. The parameters are reported in Table 12. The table contains three estimates of the distribution rule of married white families based on the $1972 / 73$ regressions of adult clothing and adult goods, and on the $1960 / 61$ estimate of the adult clothing regression. All three estimates are identical: the marginal propensity of parents' consumption is 0.75 and the constant term $\beta_{0}+\beta_{1} \bar{s}$ (estimated at the point of means) is negligible. Consequently, the marginal and the average propensities are very close - the parents' share in total consumption is $0.77-0.80$.

Based on the $1972 / 73$ findings, the marginal propensity of parents' consumption in black families does not differ much from that of whites, and the MPC of white not-married women is substantially lower. The total consumption of white married families exceeds that of black families, which in turn exceeds that of not-married white women. The same order is maintained when one compares the estimates of parents' consumption at the point of means. There are, however, only slight differences in the estimates of children's consumption in the three 
groups. (These differences are smaller still when one compares consumption per child, given the difference in the average number of children of the three groups).

This result may come as a surprise since it is often assumed that whites invest more in their children than blacks, and that the married invest more than do the not-married. It should, of course, be treated with caution, given the important role of the constant term $\left(\beta_{0}+\beta_{1} \bar{s}\right)$ in the determination of the children's average consumption, where many of the estimates used to derive this term for blacks and the not-married are not statistically significant. 27 It may, however, also be argued that the differences in parents' pecuniary investment in their children are indeed very small, and that the major difference lies in the investment of non-pecuniary resources. Thus, mothers in white families reported working an average of 15 weeks in $1972 / 73$, whereas the corresponding figures for blacks and the not-married are 26 and 28, respectively. The difference in the time inputs invested in children (and the quality of these inputs) may be a major contributor to the difference in the quality of children.

How does the number of children affect the distribution rule? Given the high multicollinearity between $K_{i}$ and the interaction term "consumption $\times K_{i} " I$ could not separate in Section $V$ the effect of fixed costs of children from that of a change in the marginal propensity to consume. Table 3 therefore contains three estimates of the consumption function of adult clothing of white families - an unrestricted one, one that assumes that the numer of children does not affect the MPC, and one that assumes that children do not involve fixed costs [equations (2), (3) and (4) in Table 3]. Correspondingly, I estimated three distribution rules (columns 1-3 in Table 13). In spite of the difference in parameters, the estimates of parents' and children's consumption are unanimous. The parents' share in total consumption is, on average, 85 percent when the family 
has one child, drops to 76 percent when the family has two children, and to 68 percent when it has three. Additional children, however, are associated, with increased consumption. 28 Consequently, the decline in parents' share involves only a miniscule decline in their absolute consumption.

Children's consumption increases with their number as a result of both the increase in their share and in total family consumption. The increase is, however, less than proportionate, and consequently the expenditure per child declines as the number of children increases (the expenditure per child in a family with three children is 80 percent of those in a family with one child). there is no way of telling whether the negative correlation between the number of children and the expenditures per child reflects returns to scale in home production or substitution between the number of children and their "quality." The constant term in the distribution rule $h$ reflects the difference between the fixed costs of parents and children. Given the estimate of h for families with one child, one cannot isolate the fixed costs of the first child without knowledge of the fixed costs of parents. Assuming, however, that the latter are unaffected by the number of children, one can derive the fixed costs associated with additional children by comparing the constant terms in h for families of different size. By equation (13), the constant term is an estimate of $\left[\beta_{0}-\beta_{2} c(k)\right]$. Hence, dividing the differential in the constant terms by $\beta_{2}$ should yield an estimate of the incremental fixed costs.

Table 13 contains the estimates of the differential between the fixed costs of 2 and 3 children and those of one child. Unfortunately, the variance between the estimates is too large to allow definite conclusions on the division of children's consumption between fixed and variable costs. 29

The patterns revealed by the $1960 / 61$ data are almost identical to those of 1972/73. The only noticeable difference is that total family consumption does 
not increase with the number of children as sharply as in the later data. Consequently, the decline in parents' consumption and in the expenditure per child as the number of children increases is slightly greater.

\section{Concluding Comments}

This paper demonstrates again the power of combining theory and empirical estimation. Building on the most elementary principles of the theory of consumption and the economics of human resources it is shown that the assumption of separability of utilities generated by parents' and children's consumption provides the researcher with a powerful tool for empirically separating these two components of consumption. It saves the researcher from the need for ad hoc theorizing to justify the use of a specific procedure of estimation (for example, it obviates the need for explaining why the share of food in total consumption should be used as a measure of welfare).

In principle there is nothing novel either in the argument that separability is essential for identifying the intrafamily allocation of resources or in the claim that the consumption patterns of adult goods are the key to identification. In their study of the allocation of income within the household Lazear and Michael (1985) emphasize the importance of the separability assumption, but they do not follow the ramifications of this assumption in their empirical work. Rothbarth (1943) was the first to suggest that consumption patterns of adult goods can reveal the effect of demographic variables on parents' consumption. This suggestion was followed by Nicholson (1949) and many others. Unfortunately, lacking sound theoretical groundwork, most of these estimates suffer from a misspecification of the estimation function. 
Most studies of the effect of demographic variables on demand assume that this effect is additive, ignoring its effect on the MPC (i.e., implicitly assuming that the redistribution of income does not affect the MPC). Imposing on families, both with and without children, the same marginal propensity to consume, traditional estimates understate the MPC of childless families and overstate that of families with children [Figure 1, and Table 2, equation (2)]. Since the slope of the regression and its intercept are negatively correlated, this misspecification leads to an upward bias in the intercept of families without children and to a downward bias in the intercept of families with children [compare equation (2) and (3) in Table 2 and equations (1) and (2) in table 4]. Thus, it overstates the "fixed costs" effect of children. The covariance between slope and intercept increases with $\bar{x}$. Since total consumption and the number of children are positively correlated, the upward bias in the "fixed costs" effect (i.e., the downward bias of the intercept) is more pronounced the larger family size (in Figure $1 a_{0}>a>a_{1}>a_{2}>a_{3}$ ).

The theoretical analysis also implies that given standard utility analysis, the modified Rothbarth method is the only one that allows the separation of factors that are goods-specific from those determining the distribution rule. The identification of the distribution rule is a prerequisite for the estimation of the specific demand of children and parents in families with children, rather than vice versa (as implied by the Engel, Barten, and other methods). Our estimates indicate that married families with $1-3$ children spend on the margin one quarter, and on average 20-30 percent of their total consumption on children. There is no observable difference between whites and blacks, and the share is higher for not-married women. These estimates are extremely robust to variations in the definition of adult goods, functional form, and sources of data. 
Public policy aimed at encouraging population growth or increasing horizontal equity often tries to compensate families for the cost of children (through child allowances, tax credit, and in other ways). 30 For a compensation scheme such as this, it is important to distinguish between the fixed costs of children and other expenditures imposed on the family by the children's "needs," and those expenditure items that are discretionary and intended to improve the children's quality. The theoretical analysis implies that this is often impossible, and if possible - a very difficult task. The empirical analysis indicates that the allocation of resources within the family is not affected by the children's age structure. Thus, in as much as children's "needs" change with age, these changing needs do not affect children's consumption.

It is impossible to estimate the fixed costs associated with the first child without knowledge of the fixed costs of adults (i.e., parents). Our attempts to estimate the incremental fixed costs (those associated with a second or a third child) were hampered by multicollinearity. Thus, it is impossible to tell whether children's consumption increases with their number because of fixed costs, or because parents prefer to spend a larger fraction of their resources on children.

Finally, in spite of the ever increasing number of empirical studies, most economists still seem to be wary of imputations of the intrafamily allocation of resources. Hopefully, the robustness of our estimates will disperse some of these suspicions. Still, this is only a first step in an an extensive research agenda:

a. The treatment of self selection in this paper has necessarily been brief. A more detailed analysis is required allowing for the endogeneity of family size, to examine the substitution between "quantity" and "quality" of children, a central theme in the economics of fertility. 
b. A major component of the cost of children is the value of the parents' time. Our scheme should allow the incorporation of parents'time (and more specifically, mothers' time) in the analysis, and the joint estimation of the intrafamily of time and goods. 31

c. Channels of intergenerational transfers have been shown to be most important in a wide range of contexts, from intergenerational mobility and the distribution of income to the efficacy of fiscal and monetary policy. Our model ignored these issues, confining itself to a one-period framework. Its expansion to the multiperiod case should enrich our knowledge of the oft-discussed but rarely studied subject of the effect of children on consumption and saving.

Judging the richness of this further research agenda, this paper seems to be only a small first step. 
Notes

*I benefited from the comments of Gary Becker, Angus Deaton, Zvi

Grilliches, Edward Lazear, Kevin Murphy, Robert Michael, Eytan Sheshinski, Menachem Yaari, Shlomo Yitzhaki and participants in workshops at the National Bureau of Economic Research, the University of Chicago, the University of Wisconsin at Madison, Columbia University and the Hebrew University. This study would not have been possible without the devoted work of my research assistant Tamir Hay.

1. For a most recent manifestation see Deaton and Muellbauer (1986). For an earlier discussion of the state of the art, see Deaton and Muellbauer ( 1980 , (h. 8).

2. It is often claimed that demographic changes affect the relative prices confronting the family. By this argument the price of goods that are more sensitive to demographic factors (e.g., changes in family size) change relatively to those goods which are less sensitive. I have shown elsewhere (Gronau, 1986) that these changes in the Barten prices are endogenous, and an outcome of family decision, rather than determining family decisions.

3. I ignore throughout the analysis "family goods". The formulation of the model is very similar to that of Samuelson's seminal paper (1956).

4. A different way of formulating the difference in the utility function is in terms of Becker's home production analysis, where $U^{j}=U^{j}\left(z_{i}^{j}\right)$, and the commodities $z_{i}^{j}$ are in the case of children $z_{i}^{B}=q_{i}^{B} / \rho_{i}$.

5. In the framework of a linear expenditure system (i.e., when $U^{B}$ is a Stone-Geary function) C stands for the cost of the minimum requirements. These minimum requirements can be incorporated directly in the utility function by writing $U^{B}=U^{B}\left[\left(q_{i}^{B}-c_{i}\right) / \rho_{i}\right]$, where $\Sigma p_{i} c_{i}=C$.

6. Alternatively, one can assume that the utility function is separable in goods and leisure (as it is in current and future consumption). To introduce 
returns to scale one has to reformulate the utility functions in terms of commodities $z_{i}$, which in turn are a function of goods and family size. We do not intend to exploit this approach in this paper.

7. A method often suggested (and much debated) in the literature is to derive the scales from information on price elasticities.

8. For further discussion of the implications of two-stage budgeting see Strotz (1957, 1959) and Gorman (1959).

9. Our purpose is not served by goods consumed exclusively by children since we do not usually observe "parentless" families (i.e., families consisting only of children). Even if they exist, they should be removed from the sample because decisions in them are not made by parents.

10. Barnes and Gillingham (1984) have recently employed inter-city variation in prices and changes in prices over the sampling period to derive the price effects from the 1972-73 Consumer Expenditure Survey. I ignore this variation. More importantly, I assume that the existence of children does not affect the price of goods (e.g., the price of a visit to the theatre may include, for a family with children, the cost of a babysitter). This assumption can be more easily defended as long as we do not incorporate the cost of time in the analysis.

11. These data have been used extensively for the estimation of adult equivalence scales (Barnes and Gillingham, 1984; Espenshade, 1984; Lazear and Michael, 1985; Turchi, 1983; Van der Gaag and Smolensky, 1982).

12. Changes in housing arrangements (and other consumption patterns) following marriage are indicative of this change (and the underlying utility function) as much as of changes in needs or returns to scale.

13. Running separate regressions for tobacco and alcoholic beverages yields results which are consistent with the theory but inconclusive in a statistical sense. 
14. Women did not report their education in 1972 . Using the 1973 subsample shows that replacing the husband's education with that of the wife does not change the results.

15. Note that since $K$ denotes the existence of children, the coefficient of $K_{2}$ measures the incremental effect of a second child and that of $K_{3}$ the incremental effect of three children compared to having only one.

16. On the average adult goods exceed adult clothing by 50 percent.

17. Deaton has called this a test for "demographic separability" (Deaton, RuizCasti110, Thomas, 1985).

18. The coefficients of "consumption," "consumption $x \mathrm{~K}$," and "consumption $\times$ K2+" are $0.1664,-0.0724$, and -0.0343 (with $t$ values of $23.38,4.45$, and 1.83 ), respectively, where $\mathrm{K} 2+$ is the dummy variable denoting the existence of two children or more.

19. Estimating a quadratic function with a dummy variable $K$ denoting children, let $a_{1}$ denote the coefficient $x^{2}$ and $a_{2}$ that of $k x^{2}$ then est $\left(\beta_{1}\right)=\left[1+\left(a_{2} / a_{1}\right)\right]^{1 / 2}$. In principle it is also possible to derive $\beta_{1}$ from the coefficients of $x$ and the constant terms, but this procedure becomes very complicated when one allows for the existence of environmental variables. 20. The only exception is the case of the quadratic function where the implied marginal propensity of parents' consumption is 0.6 . 21. Applying the same restriction to the $1972 / 73$ sample does not affect the results. Another difference between the two samples is the high percentage of rural families in the $1960 / 61$ sample (44 vs. 19 in 1972/73). Restricting the 1960/61 sample to urban families does not affect the results.

22. In the absence of data on number of weeks worked by the wife I used a dummy variable denoting the women's labor force participation, and instead of "number 
of children 0-5," I used a variable denoting that the youngest child is 5 years old or younger.

23. Removing the age restriction, the MPC declines by 17-20 percent. Restricting the sample to those under 50 , the decline in the MPC of adult clothing is much lower, but the decline in the MPC of adult goods is 20 percent.

24. The estimate for adult clothing is not statistically significant.

25. I would prefer to use the wife's schooling but this information was available only for part of the sample (see n. 14). I subtracted the wife's earnings from income because they depend heavily on the wife's labor supply which, in turn, depends on the existence of children. Income is measured in units of $\$ 10,000$. The $1972 / 73$ sample consisted of 4,240 families of whom 75 percent had children.

26. An additional qualification should be added. The variables CONSUMPTION and e.CONSUMPTION are highly correlated in the sample without children $(r=0.88)$ and not correlated in the sample with children $(r=0.20)$. The results reported in Table 10 may therefore be affected by multicollinearity. The results, however, are replicated in a sample where the husband's age does not exceed 50 . 27. This is particularly true for the $1960 / 61$ estimates for these two groups. 28. The direction of causality is, of course, not clear.

29. Another source of difficulty is the interpretation of the effect women's market work has on the distribution rule. The estimates are based on the implicit assumption that working mothers cut their own consumption in favor of their children to compensate them for smalier time inputs devoted to childcare. Had I assumed that the negative coefficient reflects increased fixed costs of children, the estimates of the fixed costs should have been considerably lower (because the wife's weeks of work decline as number of her children increases). 
30. The welfare implications of such compensation schemes are discussed in Gronau (1985).

31. Two studies that discuss the joint decision of consumption and labor supply are Abbot and Ashenfelter (1976) and Atkinson and Stern (1979). The value of mothers' time is often incorporated in estimates of the cost of children, but is consistently ignored in estimates of adult equivalence scales. 


\section{References}

Abbot, M. and Ashenfelter, O. (1976). "Labor Supply, Commodity Demand, and the Allocation of Time," Review of Economic Studies, 43: 389-412.

Atkinson, A.B. and Stern, N.H. (1979). "On Labor Supply and Commodity Demands", SSRC Programme Taxation, Incentives and Distribution of Income, No. 1.

Atkinson, A.B., Gomulka, J. and Stern, N.H. (1984a). "Household Expenditures on Tobacco 1970-1980: Evidence from the Family Expenditure Survey," ESRC Programme on Taxation Incentives and the Distribution of Income, Discussion Paper 37.

\section{(1984b). "Expenditure on Alcoholic Drink by Households:}

Evidence from the Family Expenditure Survey," ESRC Programme on Taxation Incentives and the Distribution of Income, Discussion Paper 60.

Barnes, R. and Gillingham, R. (1984). "Demographic Effects in Demand Analysis: Estimation of the Quadratic Expenditure System Using Microdata," eview of Economics and Statistics, 66(4): 591-601.

Barten, A.P. (1964). "Family Composition, Prices and Expenditure Patterns," in P.E. Hart et al., eds., Econometric Analysis for National Planning, London: Butterworth.

Becker, G.S. and Lewis, H.G. (1973). "Interaction Between Quantity and Quality of Children," Journal of Political Economy, 81(2), Part 2.

Deaton, A. and Muellbauer, J. (1980). Economics and Consumer Behavior. New York: Cambridge University Press.

(1986). "On Measuring Child Costs with Applications to Poor Countries," Journal of Political Economy, forthcoming. 
Deaton, A., Ruiz-Castillo, Z. and Thomas, D. (1985). "The Influence of Household Expenditure Patterns," Research Program in Development Studies, Woodrow Wilson School, Princeton University, Discussion Paper 122.

Engel, E. (1895). "Die Lebenskosten Belgischer Arbeiter - Familien Fruher und Jetzt," Inst. Stat. Inst. Bull, no. 9.

Espenshade, T.J. (1984). Investing in Children. Washington, D.C.: Urban Institute.

Gorman, W.M. (1959). "Separable Utility and Aggregation," Econometrica, 27(3): $469-481$

Gronau, R. (1986). "Consumption Technology and the Intrafamily Distribution of Resources - Adult Equivalence Scales Reexamined,"Jerusalem: The Maurice Falk Institute for Economic Research in Israel, Discussion Paper No. 85.11.

Lazear, E.P. and Michael, R.T. (1985). "Allocation of Income Within the Household," mimeo (January).

Nicholson, J.L. (1949). "Variations in Working Class Family Expenditures," Journal of the Royal Statistical Society A, $112: 359-411$.

Rothbarth, E. (1943). "Note on a Method of Determining Equivalent Incomes for Families of Different Composition," Appendix IV in C. Madge, War-Time Patterns of Saving and Spending, Occasional Paper No. 4, National Inst. of Econ. and Soc. Res., London: Macmillan.

Samuelson, P.A. (1956). "Social Indifference Curves," Quarterly Journal of Economics, $70(1): 1-22$.

Strotz, R.H. (1957). "The Empirical Implications of a Utility Tree," Econometrica, 25(2): 269-280. 
(1959). "The Utility Tree - a Correction and Further Appraisal," Econometrica, $27(3): 482-488$.

Turchi, B.A. (1983). Estimating the Costs of Children in the United States. Carolina Population Center, University of North Carolina.

Van der Gaag, J. and Smolensky, E. (1982). "True Household Equivalence Scales and Characteristics of the Poor in the United States," Review of Income and Wealth, 28(1): 17-28. 
Table 1: White Married Families (1972/73)

Sample Means

\begin{tabular}{|c|c|c|c|c|c|c|}
\hline & & & Number & of chi & ren & \\
\hline & $\begin{array}{l}\text { Total } \\
\text { sample }\end{array}$ & 0 & 1 & 2 & 3 & $1-3$ \\
\hline Husband's educ. & 12.0 & 11.4 & 12.6 & 13.0 & 12.6 & 12.8 \\
\hline Husband's age & 44.7 & 53.9 & 33.7 & 33.9 & 35.5 & 34.2 \\
\hline Husband employed & 0.84 & 0.72 & 0.97 & 0.98 & 0.98 & 0.98 \\
\hline Wife employed & 0.48 & 0.48 & 0.55 & 0.45 & 0.40 & 0.48 \\
\hline $\begin{array}{l}\text { Husband's weeks } \\
\text { of work }\end{array}$ & 39 & 32 & 46 & 48 & 48 & 47 \\
\hline $\begin{array}{l}\text { Wife's weeks } \\
\text { of work }\end{array}$ & 17 & 19 & 18 & 14 & 13 & 15 \\
\hline $\begin{array}{l}\text { Number of children } \\
0-5 \text { years }\end{array}$ & 0.40 & 0 & 0.63 & 0.98 & 0.99 & 0.85 \\
\hline North central & 0.29 & 0.29 & 0.28 & 0.27 & 0.29 & 0.28 \\
\hline West & 0.20 & 0.20 & 0.22 & 0.22 & 0.19 & 0.21 \\
\hline South & 0.29 & 0.30 & 0.31 & 0.28 & 0.28 & 0.29 \\
\hline Rural & 0.19 & 0.20 & 0.16 & 0.17 & 0.20 & 0.17 \\
\hline Family income ( $\$$ ) & 12,556 & 11,483 & 12,483 & 14,141 & 15,301 & 13,779 \\
\hline Total consumption (\$) & 8,487 & 7,527 & 8,829 & 9,779 & 10,492 & 9,582 \\
\hline Expenditures (\$) & & & & & & \\
\hline Adult goods & 647 & 628 & 675 & 672 & 653 & 669 \\
\hline Adult clothing & 432 & 431 & 440 & 437 & 413 & 433 \\
\hline Male clothing & 178 & 167 & 193 & 190 & 184 & 190 \\
\hline Female clothing & 254 & 264 & 247 & 247 & 230 & 243 \\
\hline Number of observations & 7,793 & 4,153 & 1,339 & 1,520 & 781 & 3,640 \\
\hline Percent & 100 & 53 & 17 & 20 & 10 & 47 \\
\hline
\end{tabular}


Table 2: The Effect of Children on the Consumption of Adult Clothing White Married Families $1972 / 1973$

\begin{tabular}{|c|c|c|c|c|c|c|c|c|}
\hline & \multicolumn{2}{|l|}{ (1) } & \multicolumn{2}{|l|}{$(2)$} & \multicolumn{2}{|l|}{ (3) } & \multicolumn{2}{|l|}{ (4) } \\
\hline & b & $t$ & $\mathrm{~b}$ & $t$ & $\mathbf{b}$ & t & b & $t$ \\
\hline Constant & -260.312 & 15.72 & -250.456 & 15.40 & -313.506 & 18.12 & -316.762 & 15.72 \\
\hline $\begin{array}{l}\text { Husband's } \\
\text { education }\end{array}$ & 10.264 & 7.15 & 13.608 & 9.57 & 12.759 & 9.01 & 12.504 & 6.79 \\
\hline $\begin{array}{l}\text { Husband's } \\
\text { educ. } \times k\end{array}$ & & & & & & & -0.456 & 0.16 \\
\hline $\begin{array}{l}\text { Wife's weeks } \\
\text { of work } \times k\end{array}$ & & & & & & & -1.309 & 3.32 \\
\hline Consumption & 0.0637 & 60.15 & 0.0670 & 63.37 & 0.0770 & 53.64 & 0.0764 & 51.49 \\
\hline $\begin{array}{l}\text { Consumption } \\
\times \mathrm{K}\end{array}$ & & & & & -0.0198 & 10.21 & -0.0186 & 8.86 \\
\hline
\end{tabular}




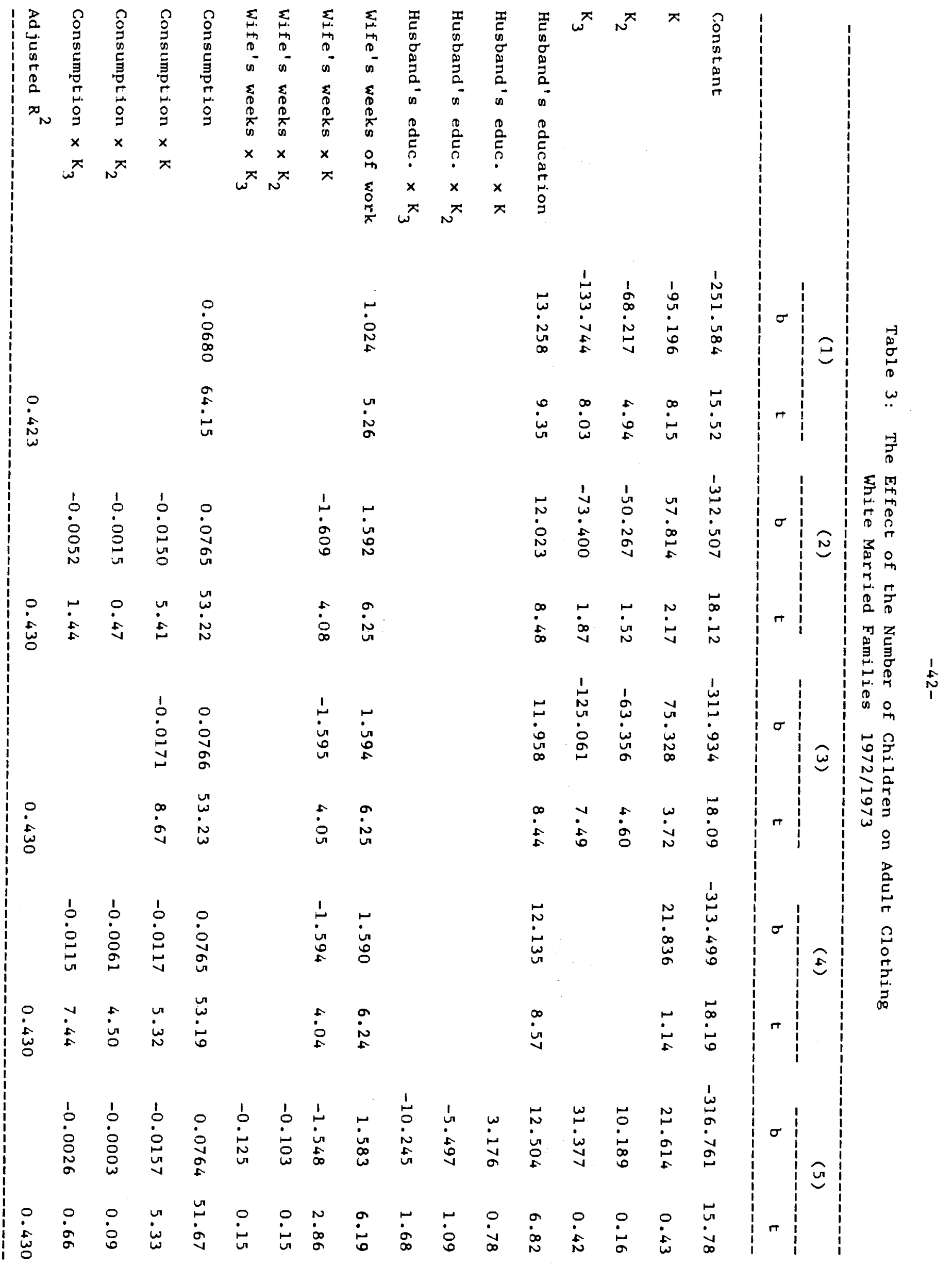


Table 4: The Effect of Children on the Consumption of Adult Goods

\begin{tabular}{|c|c|c|c|c|c|c|}
\hline & ( & --- & $(2)$ & - & $(3)$ & \\
\hline & b & $\mathrm{t}$ & b & $t$ & b & $\mathrm{t}$ \\
\hline Constant & -63.387 & 1.34 & -175.666 & 3.67 & -351.803 & 5.61 \\
\hline K & -201.508 & 15.59 & 49.510 & 1.98 & 478.729 & 4.28 \\
\hline $\begin{array}{l}\text { Husband's } \\
\text { education }\end{array}$ & 2.072 & 1.14 & 1.918 & 1.06 & 6.144 & 2.55 \\
\hline $\begin{array}{l}\text { Husband's } \\
\text { educ. } \times \mathrm{k}\end{array}$ & & & & & -8.327 & 2.27 \\
\hline $\begin{array}{l}\text { Husband's } \\
\text { age }\end{array}$ & 6.700 & 3.58 & 5.994 & 3.23 & 10.576 & 4.69 \\
\hline $\begin{array}{l}\text { Husband's } \\
\text { age } \times x\end{array}$ & & & & & -14.726 & 2.74 \\
\hline$(\text { Age })^{2}$ & -0.101 & 5.21 & -0.087 & 4.50 & -0.124 & 5.49 \\
\hline$(\text { Age })^{2} \times K$ & & & & & 0.145 & 2.21 \\
\hline Rural & -55.162 & 4.15 & -52.719 & 4.00 & $-45 \cdot 364$ & 2.57 \\
\hline Rural $\times \mathrm{K}$ & & & & & -15.754 & 0.59 \\
\hline $\begin{array}{l}\text { Wife's weeks } \\
\text { of work }\end{array}$ & 0.923 & 3.83 & 0.884 & 3.62 & 1.554 & 4.62 \\
\hline $\begin{array}{l}\text { Wife's weeks } \\
\text { of work } \times x\end{array}$ & & & & & -1.329 & 2.70 \\
\hline Consumption & 0.0835 & 63.11 & 0.0975 & 54.83 & 0.0958 & 51.75 \\
\hline Consumption $\times \mathrm{K}$ & & & -0.0276 & 11.66 & -0.0235 & 8.94 \\
\hline Adjusted $\mathbf{R}^{2}$ & & 0.428 & & 0.438 & & 0.439 \\
\hline
\end{tabular}




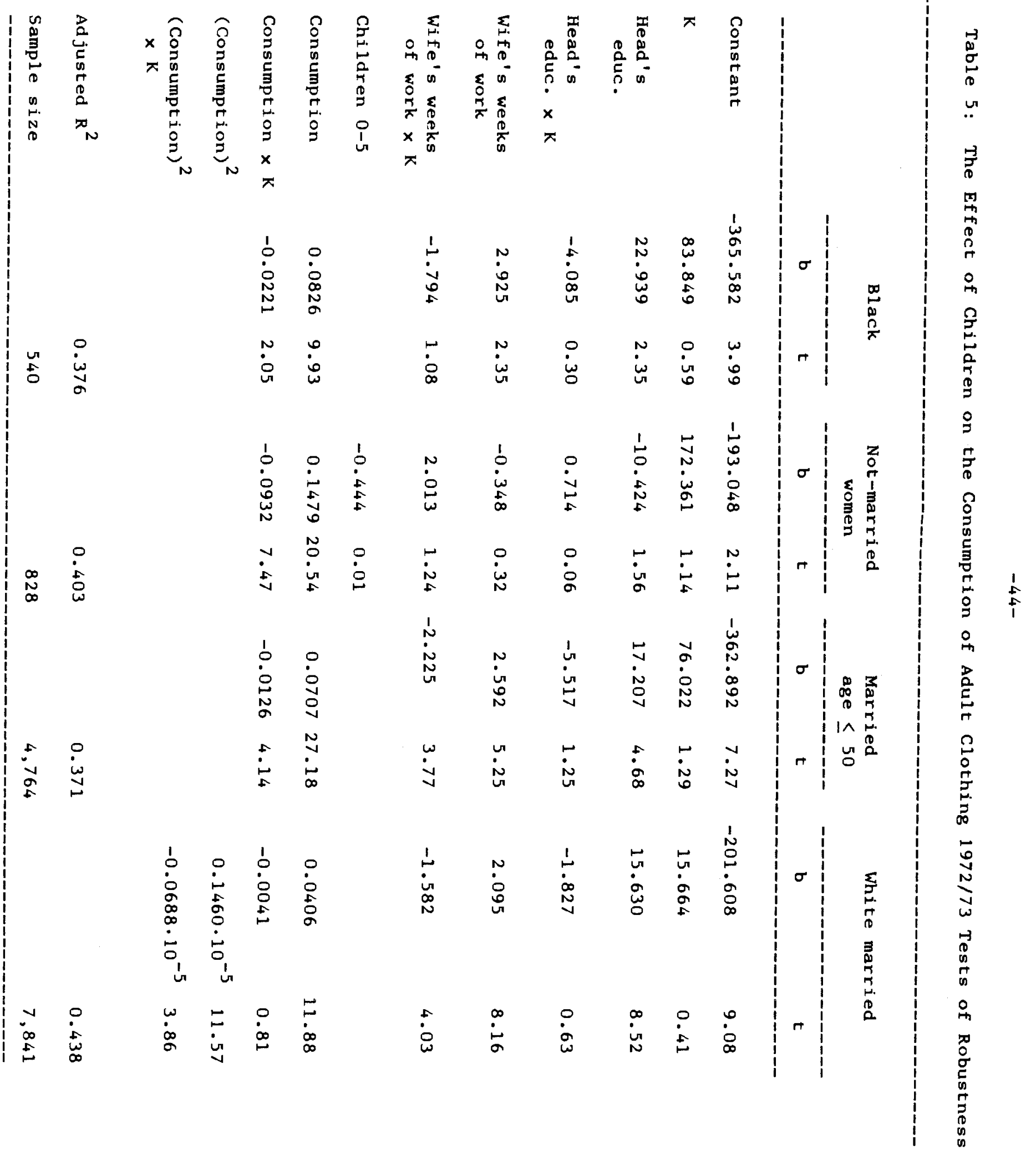


Table 6: White Married Families 1960/1961

Samle Means

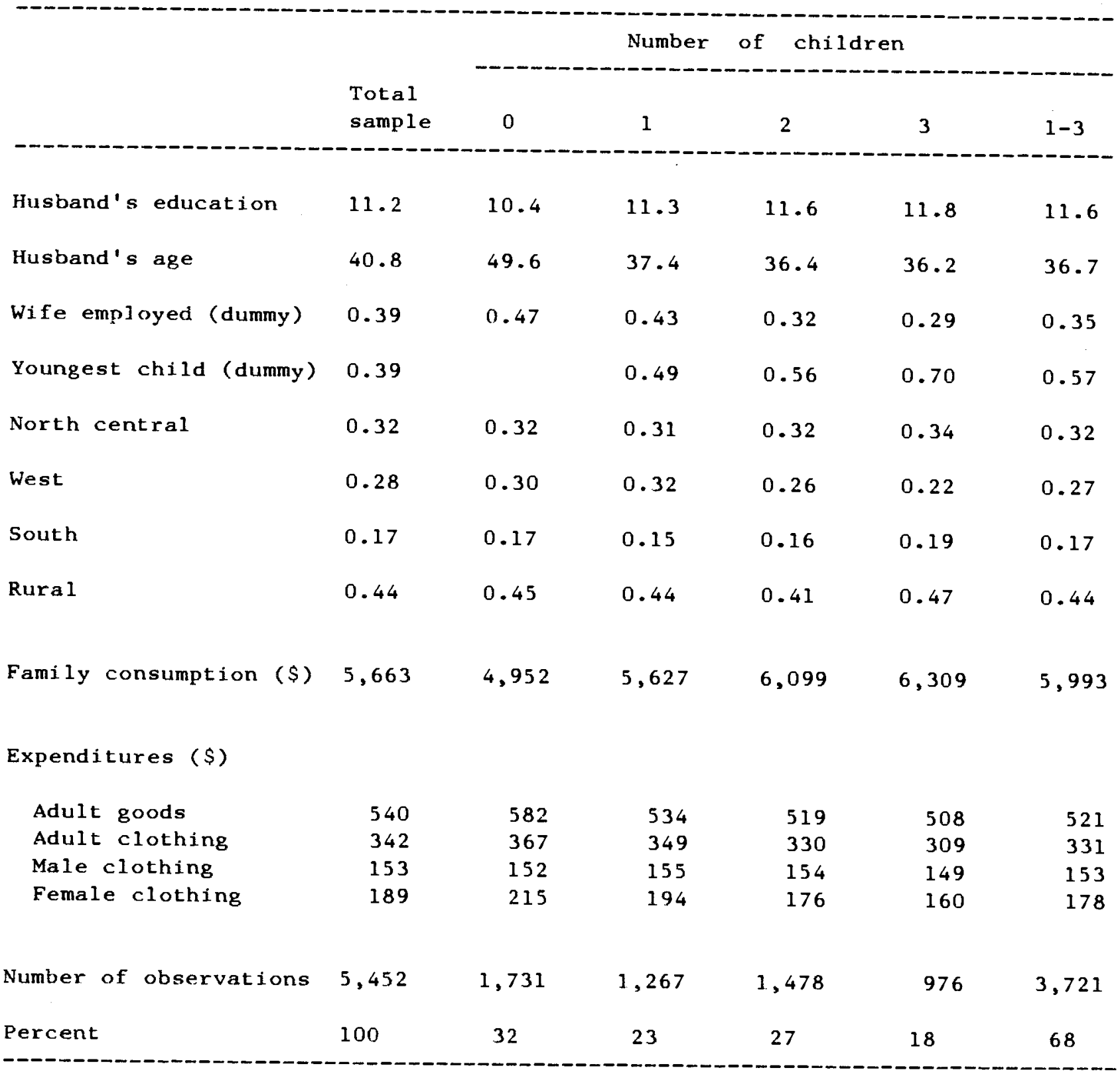


Table 7: The Effect of Children on the Consumption of Adult Clothing 1960/61: White, Black, Not-Married

\begin{tabular}{|c|c|c|c|c|c|c|c|c|}
\hline & \multicolumn{4}{|c|}{ White married families } & \multicolumn{2}{|c|}{ Black married } & \multicolumn{2}{|c|}{ White not-married } \\
\hline & $\mathrm{b}$ & $t$ & b & $t$ & b & $\mathrm{t}$ & b & $\mathrm{t}$ \\
\hline Constant & $-14 \cdot 930$ & 6.76 & -84.492 & 1.87 & 260.528 & 1.64 & 359.772 & 5.28 \\
\hline $\mathbf{K}$ & 28.467 & 1.73 & 11.373 & 0.57 & -96.265 & 1.61 & -60.237 & 2.31 \\
\hline $\mathrm{K}_{2}$ & & & 28.721 & 1.36 & & & & \\
\hline $\mathrm{K}_{3}$ & & & -57.534 & 2.44 & & & & \\
\hline $\begin{array}{l}\text { Head's } \\
\text { education }\end{array}$ & -0.377 & 0.35 & -0.531 & 0.50 & 1.957 & 0.53 & 1.568 & 0.87 \\
\hline $\begin{array}{l}\text { Head's } \\
\text { age }\end{array}$ & -5.586 & 7.55 & -1.529 & 0.71 & -11.741 & 1.57 & -13.703 & 4.31 \\
\hline$(\text { Age })^{2}$ & 0.064 & 2.57 & -0.016 & 0.62 & 0.093 & 1.07 & 0.099 & 2.70 \\
\hline Wife employed & 24.336 & 3.73 & 19.085 & 2.93 & 12.157 & 0.52 & 38.277 & 2.63 \\
\hline $\begin{array}{l}\text { Youngest } \\
\text { child } \leq 5\end{array}$ & -28.183 & 3.13 & -13.021 & 1.42 & 13.275 & 0.36 & -63.730 & 2.72 \\
\hline N. central & -1.743 & 0.21 & -1.880 & 0.23 & -71.182 & 2.02 & 19.634 & 1.38 \\
\hline West & 5.153 & 0.59 & 2.791 & 0.32 & -29.345 & 0.87 & 37.979 & 2.64 \\
\hline South & -38.936 & 3.96 & -38.029 & 3.90 & -133.082 & 2.68 & 24.639 & 1.58 \\
\hline Rural & 17.981 & 2.73 & 21.277 & 3.25 & 30.689 & 1.02 & -12.676 & 1.08 \\
\hline Consumption & 0.0973 & 44.30 & 0.0972 & 44.55 & 0.1112 & 11.64 & 0.0867 & 18.76 \\
\hline Consump. $\times \mathrm{K}$ & -0.0239 & 9.56 & -0.0160 & 5.07 & -0.0133 & 1.15 & -0.0321 & 5.24 \\
\hline Consump. $\times \mathrm{K}_{2}$ & & & -0.0133 & 4.08 & & & & \\
\hline Consump. $\times \mathrm{K}_{3}$ & & & -0.0048 & 1.35 & & & & \\
\hline Adjusted $\mathrm{R}^{2}$ & & 0.476 & & 0.484 & & 0.474 & & 0.527 \\
\hline $\begin{array}{l}\text { Number of } \\
\text { observations }\end{array}$ & & 5,452 & & 5,452 & & 417 & & 889 \\
\hline
\end{tabular}


Table 8: The Effect of Children on the Consumption of Adult Goods 1960/61: White, Black, Not Married

\begin{tabular}{|c|c|c|c|c|c|c|c|c|}
\hline & \multicolumn{4}{|c|}{ White married families } & \multicolumn{2}{|c|}{ Black married } & \multicolumn{2}{|c|}{ White not-married } \\
\hline & b & $t$ & b & $\mathrm{t}$ & b & t & b & $t$ \\
\hline Constant & -118.749 & 1.97 & -212.577 & 3.47 & 166.185 & 0.78 & 361.820 & 4.51 \\
\hline K & 16.484 & 0.76 & 16.539 & 0.63 & -81.696 & 1.01 & -74.342 & 2.43 \\
\hline $\mathrm{K}_{2}$ & & & 4.286 & 0.49 & & & & \\
\hline $\mathrm{k}_{3}$ & & & -109.846 & 3.52 & & & & \\
\hline $\begin{array}{l}\text { Head's } \\
\text { education }\end{array}$ & -6.430 & 4.54 & $\begin{array}{c}-6.593 \\
.\end{array}$ & 4.69 & 0.696 & 0.14 & -1.719 & 0.81 \\
\hline $\begin{array}{l}\text { Head's } \\
\text { age }\end{array}$ & 6.512 & 2.32 & 11.836 & 4.13 & -1.966 & 0.19 & -9.446 & 2.52 \\
\hline$(\text { Age })^{2}$ & -0.088 & 2.66 & -0.151 & 4.48 & -0.031 & 0.26 & 0.031 & 0.73 \\
\hline Wife employed & 33.912 & 3.93 & 27.520 & 3.20 & 64.799 & 2.07 & 43.887 & 2.56 \\
\hline $\begin{array}{l}\text { Youngest } \\
\text { child } \leq 5\end{array}$ & -13.367 & 1.12 & 5.703 & 0.47 & 18.539 & 0.37 & -78.429 & 2.85 \\
\hline N. Central & -20.616 & 1.86 & -20.709 & 1.88 & -114.851 & 2.41 & 2.301 & 0.14 \\
\hline West & -39.875 & 3.43 & -43.502 & 3.76 & -86.873 & 1.92 & 14.618 & 0.87 \\
\hline South & -49.729 & 3.83 & -49.063 & 3.80 & -182.636 & 2.73 & 26.543 & 1.45 \\
\hline Rural & 1.585 & 0.18 & 5.418 & 0.62 & 24.909 & 0.61 & -18.545 & 1.35 \\
\hline Consumption & 0.1379 & 47.46 & 0.1377 & 47.71 & 0.1499 & 11.61 & 0.1133 & 20.83 \\
\hline Consump. $\times \mathrm{K}$ & -0.0370 & 11.21 & -0.0305 & 7.33 & -0.0296 & 1.89 & -0.0417 & 5.71 \\
\hline Consump. $\times \mathrm{K}_{2}$ & & & -0.0123 & 2.83 & & & & \\
\hline Consump. $\times \mathrm{K}_{3}$ & & & -0.0004 & 0.09 & & & & \\
\hline Adjusted $R^{2}$ & & 0.510 & & 0.516 & & 0.482 & & 0.566 \\
\hline $\begin{array}{l}\text { Number of } \\
\text { observations }\end{array}$ & & 5,452 & & 5,452 & & 417 & & 889 \\
\hline
\end{tabular}


Table 9: Tests for Separability: The Consumption of Male and Female Clothing, Tobacco and Alcoholic Beverages $1972 / 73$

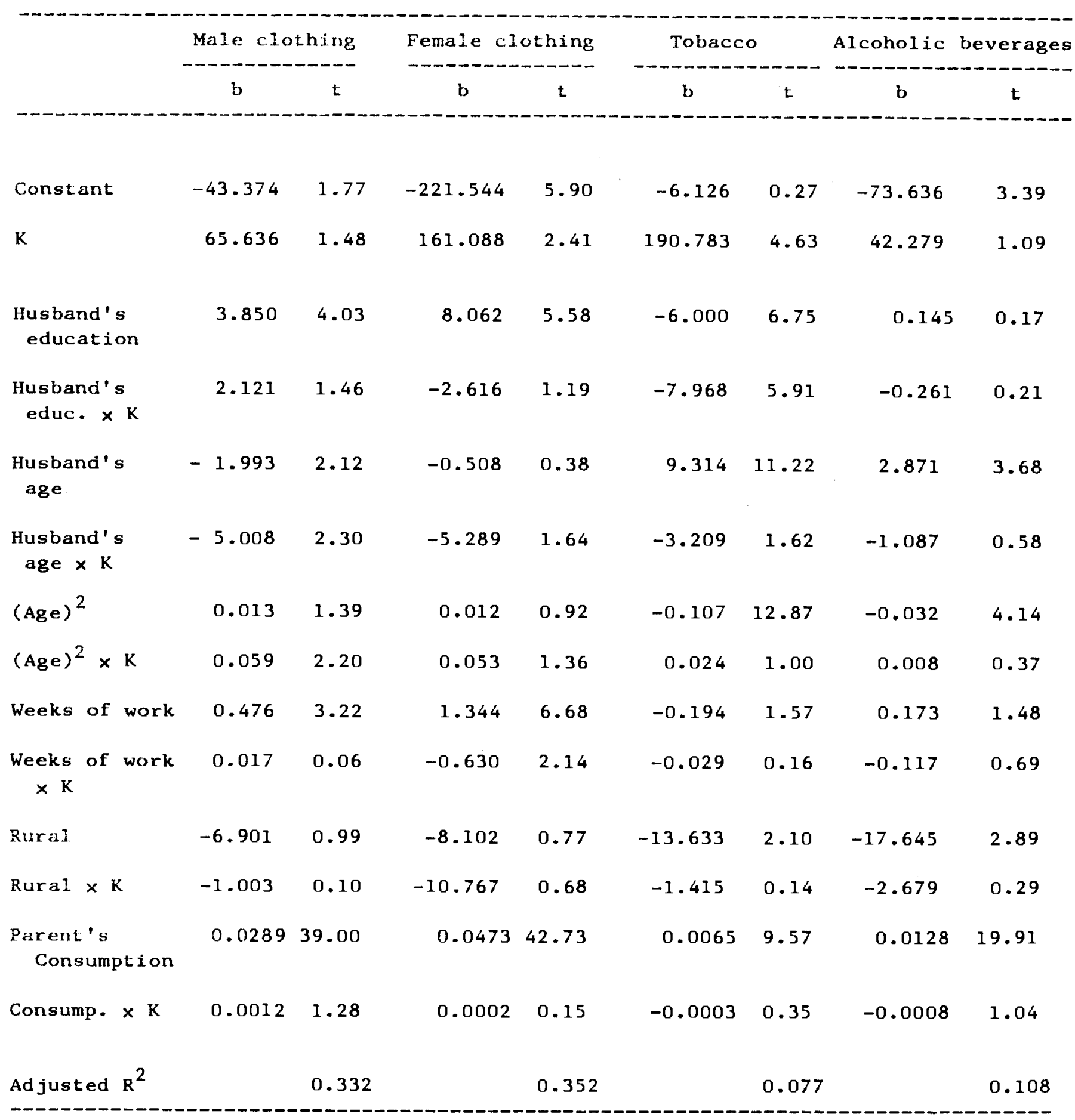


Table 10: Tests for Selectivity Bias: The Consumption of Adult Clothing White Married Families with No Children 1972/73

\begin{tabular}{|c|c|c|c|c|c|c|}
\hline & \multicolumn{2}{|c|}{ (1) } & \multicolumn{2}{|l|}{ (2) } & \multicolumn{2}{|l|}{ (3) } \\
\hline & b & $\mathrm{t}$ & $\mathrm{b}$ & $\mathrm{t}$ & b & t \\
\hline Constant & -768.835 & 2.91 & -739.964 & 2.80 & -676.272 & 2.51 \\
\hline $\begin{array}{l}\text { Husband's } \\
\text { education }\end{array}$ & 13.349 & 2.46 & 20.496 & 2.80 & 20.214 & 2.76 \\
\hline $\begin{array}{l}\text { Husband's } \\
\text { age }\end{array}$ & 28.376 & 1.56 & 16.402 & 0.82 & 18.954 & 0.95 \\
\hline$(\text { Age })^{2}$ & -0.427 & 1.47 & -0.290 & 0.95 & -0.329 & 1.15 \\
\hline $\begin{array}{l}\text { Wife's weeks } \\
\text { of work }\end{array}$ & 2.418 & 3.45 & 2.313 & 3.28 & 2.405 & 3.39 \\
\hline N. central & -27.298 & 0.68 & -26.519 & 0.66 & -25.452 & 0.64 \\
\hline West & -14.075 & 0.33 & $-13 \cdot 307$ & 0.31 & -13.195 & 0.31 \\
\hline South & 77.761 & 1.95 & 80.672 & 2.03 & 80.683 & 2.03 \\
\hline Rural & -39.872 & 1.00 & -48.518 & 1.20 & -48.205 & 1.19 \\
\hline Consumption & 0.0740 & 20.35 & 0.0719 & 18.51 & 0.0592 & 5.16 \\
\hline "Taste" for & & & & & & \\
\hline children-e & & & -185.761 & 1.45 & -28.136 & 0.15 \\
\hline$e x$ consumption & & & & & -0.0188 & 1.18 \\
\hline Adjusted $R^{2}$ & & 0.357 & & 0.358 & & 0.358 \\
\hline $\begin{array}{l}\text { Number of } \\
\text { observations }\end{array}$ & & 1072 & & 1072 & & 1072 \\
\hline
\end{tabular}


Table 11: The Effect of the "Taste" for Children On Children's Consumption: The Consumption of Adult Clothing White Married Families with Children 1972/73

\begin{tabular}{|c|c|c|c|c|c|c|}
\hline & \multicolumn{2}{|l|}{ (1) } & \multicolumn{2}{|l|}{ (2) } & \multicolumn{2}{|l|}{ (3) } \\
\hline & $\mathrm{b}$ & $\mathrm{t}$ & b & $\mathbf{t}$ & b & $\mathbf{t}$ \\
\hline Constant & 210.512 & 1.60 & 428.846 & 2.61 & 270.750 & 1.55 \\
\hline $\begin{array}{l}\text { Husband's } \\
\text { education }\end{array}$ & 12.373 & 5.25 & 15.508 & 5.65 & 15.077 & 5.49 \\
\hline $\begin{array}{l}\text { Husband's } \\
\text { age }\end{array}$ & -28.721 & 3.50 & -40.244 & 4.15 & -33.236 & 3.32 \\
\hline$(\text { Age })^{2}$ & 0.387 & 3.11 & 0.526 & 3.78 & 0.428 & 2.98 \\
\hline $\begin{array}{l}\text { Wife's weeks } \\
\text { of work }\end{array}$ & 0.359 & 1.14 & 0.431 & 1.36 & 0.502 & 1.58 \\
\hline $\begin{array}{l}\text { Children, } \\
\text { age } \leqslant 5\end{array}$ & -6.476 & 0.74 & -5.263 & 0.60 & -3.401 & 0.39 \\
\hline N. central & 4.146 & 0.24 & 4.242 & 0.24 & 3.732 & 0.21 \\
\hline West & 0.626 & 0.03 & -1.129 & 0.60 & -2.292 & 0.12 \\
\hline South & 36.935 & 2.10 & 38.919 & 2.21 & 38.086 & 2.16 \\
\hline Rural & -35.348 & 2.10 & -39.763 & 2.35 & -38.608 & 2.28 \\
\hline Consumption & 0.0597 & 37.93 & 0.0582 & 35.38 & 0.0626 & 28.21 \\
\hline $\begin{array}{l}\text { "Taste" for } \\
\text { children-e }\end{array}$ & & & -150.725 & 2.21 & 93.633 & 0.84 \\
\hline e $x$ consumption & & & & & -0.0268 & 2.75 \\
\hline Adjusted $R^{2}$ & & 0.382 & & 0.383 & & 0.384 \\
\hline $\begin{array}{l}\text { Number of } \\
\text { observations }\end{array}$ & & 3168 & & 3168 & & 3168 \\
\hline
\end{tabular}


Table 12: The Effect of Children on the Distribution Rule and the Intrafamily Allocation of Resources

\begin{tabular}{|c|c|c|c|c|c|c|c|}
\hline & \multicolumn{4}{|c|}{$1972 / 73$} & \multicolumn{3}{|c|}{$1960 / 61$} \\
\hline & $\frac{\text { White }}{(1)}$ & $\frac{\text { married }}{(2)}$ & $\begin{array}{c}\text { Black } \\
\text { married }\end{array}$ & $\begin{array}{l}\text { Not- } \\
\text { married }\end{array}$ & $\begin{array}{l}\text { White } \\
\text { married }\end{array}$ & $\begin{array}{c}\text { Black } \\
\text { married }\end{array}$ & $\begin{array}{l}\text { Not- } \\
\text { married }\end{array}$ \\
\hline \multicolumn{8}{|c|}{ The distribution rule: } \\
\hline Constant & $496 *$ & 4997 & $1015 *$ & $1165 *$ & 293 & $-866^{\star}$ & -695 \\
\hline $\begin{array}{l}\text { Husband's } \\
\text { education }\end{array}$ & $-5.97 *$ & -86.92 & $-49.46^{*}$ & $4.83^{*}$ & & & \\
\hline Husband's age & & -153.72 & & & & & \\
\hline$(\text { Age })^{2}$ & & 1.54 & & & & & \\
\hline Rural & & $-164.45^{*}$ & & & & & \\
\hline $\begin{array}{l}\text { Wife's weeks of } \\
\text { work }\end{array}$ & -17.13 & -13.87 & $-21.72^{\star}$ & $13.61 *$ & & & \\
\hline Consumption & 0.757 & 0.755 & 0.732 & 0.370 & 0.754 & 0.880 & 0.630 \\
\hline The Intrafamily D & istributio & & & & & & \\
\hline$\beta_{0}+\beta_{1} \bar{s}$ & 156 & 284 & -110 & 1605 & 293 & -866 & -695 \\
\hline Family Consumption & 9582 & 9582 & 8271 & 5702 & 5993 & 4610 & 3637 \\
\hline $\begin{array}{l}\text { Parent's } \\
\quad \text { Consumption }\end{array}$ & 7409 & 7519 & 5944 & 3715 & 4812 & 3190 & 1596 \\
\hline $\begin{array}{l}\text { Children's } \\
\text { Consumption }\end{array}$ & 2173 & 2063 & 2327 & 1987 & 1181 & 1420 & 2041 \\
\hline Parent's share & 0.77 & 0.78 & 0.72 & 0.65 & 0.80 & 0.69 & 0.44 \\
\hline Source: Table: & $2(\mathrm{eq} \cdot 4)$ & $4($ eq. 3$)$ & 5 & 5 & 7 & 7 & 7 \\
\hline
\end{tabular}

*Based on estimates which are statistically not significant. 
Table 13: The Effect of the Number of Children on the Distribution Rule and the Intrafamily Distribution of Resources - Married White Families

\begin{tabular}{|c|c|c|c|c|c|c|c|}
\hline \multirow{2}{*}{\multicolumn{2}{|c|}{$\begin{array}{c}\text { Number } \\
\text { of } \\
\text { children }\end{array}$}} & \multicolumn{3}{|c|}{$1972 / 73$} & \multicolumn{3}{|c|}{$1960 / 61$} \\
\hline & & (1) & (2) & (3) & $(1)$ & $(2)$ & $(3)$ \\
\hline \multicolumn{8}{|l|}{ The distribution rule } \\
\hline \multirow{3}{*}{ Constant $\left(\beta_{0}-\beta_{2} c\right)$} & 1 & 756 & 983 & 285 & 117 & 485 & 92 \\
\hline & 2 & 99 & 156 & 285 & 412 & -28 & 92 \\
\hline & 3 & -203 & -650 & 285 & -475 & -375 & 92 \\
\hline $\begin{array}{l}\text { Wife's weeks of } \\
\text { work }\left(\beta_{1}\right)\end{array}$ & & -21.03 & -20.82 & -20.84 & & & \\
\hline \multirow[t]{2}{*}{ Consumption $\left(\beta_{2}\right)$} & 1 & 0.804 & 0.777 & 0.847 & 0.835 & 0.770 & 0.841 \\
\hline & $\begin{array}{l}2 \\
3\end{array}$ & $\begin{array}{l}0.784 \\
0.736\end{array}$ & 0.777 & $\begin{array}{l}0.767 \\
0.679\end{array}$ & $\begin{array}{l}0.698 \\
0.786\end{array}$ & $\begin{array}{l}0.770 \\
0.770\end{array}$ & $\begin{array}{l}0.745 \\
0.714\end{array}$ \\
\hline \multicolumn{8}{|c|}{ The intrafamily distribution } \\
\hline \multirow[t]{3}{*}{ Family consumption } & 1 & 8829 & 8829 & 8829 & 5627 & 5627 & 5627 \\
\hline & 2 & 9779 & 9779 & 9779 & 6099 & 6099 & 6099 \\
\hline & 3 & 10492 & 10492 & 10492 & 6309 & 6309 & 6309 \\
\hline \multirow[t]{3}{*}{ Parents' consumption } & 1 & 7476 & 7468 & 7388 & 4815 & 4818 & 4824 \\
\hline & 2 & 7471 & 7463 & 7493 & 4669 & 4668 & 4636 \\
\hline & 3 & 7245 & 7232 & 7138 & 4484 & 4483 & 4597 \\
\hline \multirow{3}{*}{$\begin{array}{l}\text { Children's } \\
\text { consumption }\end{array}$} & 1 & 1353 & 1361 & 1441 & 812 & 809 & 803 \\
\hline & 2 & 2308 & 2316 & 2286 & 1430 & 1431 & 1463 \\
\hline & 3 & 3247 & 3260 & 3354 & 1825 & 1826 & 1712 \\
\hline \multirow[t]{3}{*}{ Parent's share } & 1 & 0.85 & 0.85 & 0.84 & 0.86 & 0.86 & 0.86 \\
\hline & 2 & 0.76 & 0.76 & 0.77 & 0.77 & 0.77 & 0.76 \\
\hline & 3 & 0.69 & 0.69 & 0.68 & 0.71 & 0.71 & 0.73 \\
\hline \multirow{3}{*}{$\begin{array}{l}\text { Expenditures } \\
\text { per child }\end{array}$} & 1 & 3353 & 1361 & 1441 & 812 & 809 & 803 \\
\hline & 2 & 1154 & 1158 & 1143 & 715 & 716 & 732 \\
\hline & 3 & 1082 & 1087 & 1118 & 608 & 608 & 571 \\
\hline \multirow{2}{*}{$\begin{array}{l}\text { Fixed costs of } \\
\text { children }\end{array}$} & 2 & 833 & 1064 & 0 & -423 & 594 & 0 \\
\hline & 3 & 1303 & 2102 & 0 & 753 & 1117 & 0 \\
\hline
\end{tabular}


Table Al: The Consumption of Adult Clothing by Number of Children White Married Families $1972 / 73$

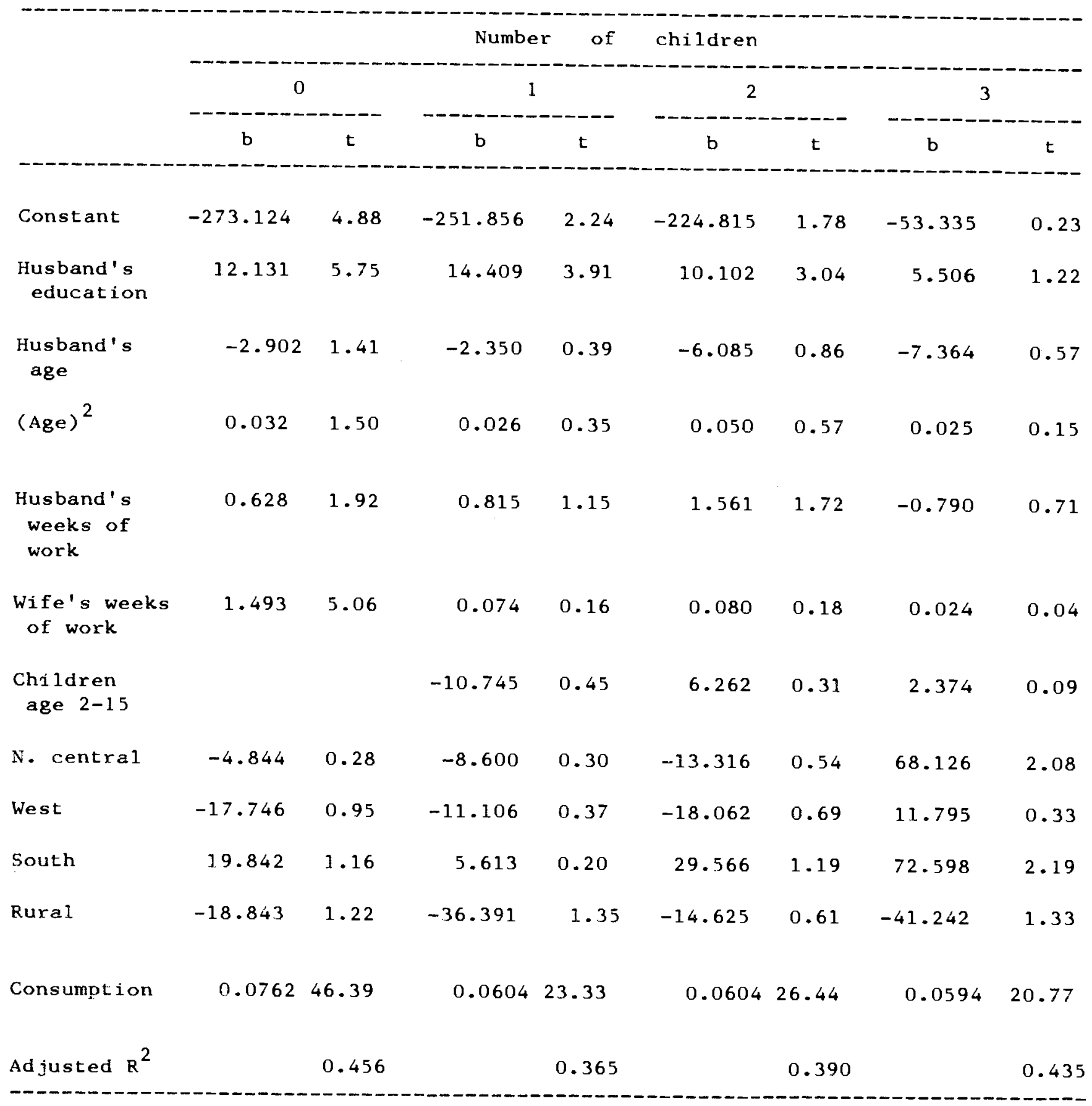


Table A2: The Consumption of Adult Goods by Number of Children

White Married Families $1972 / 73$

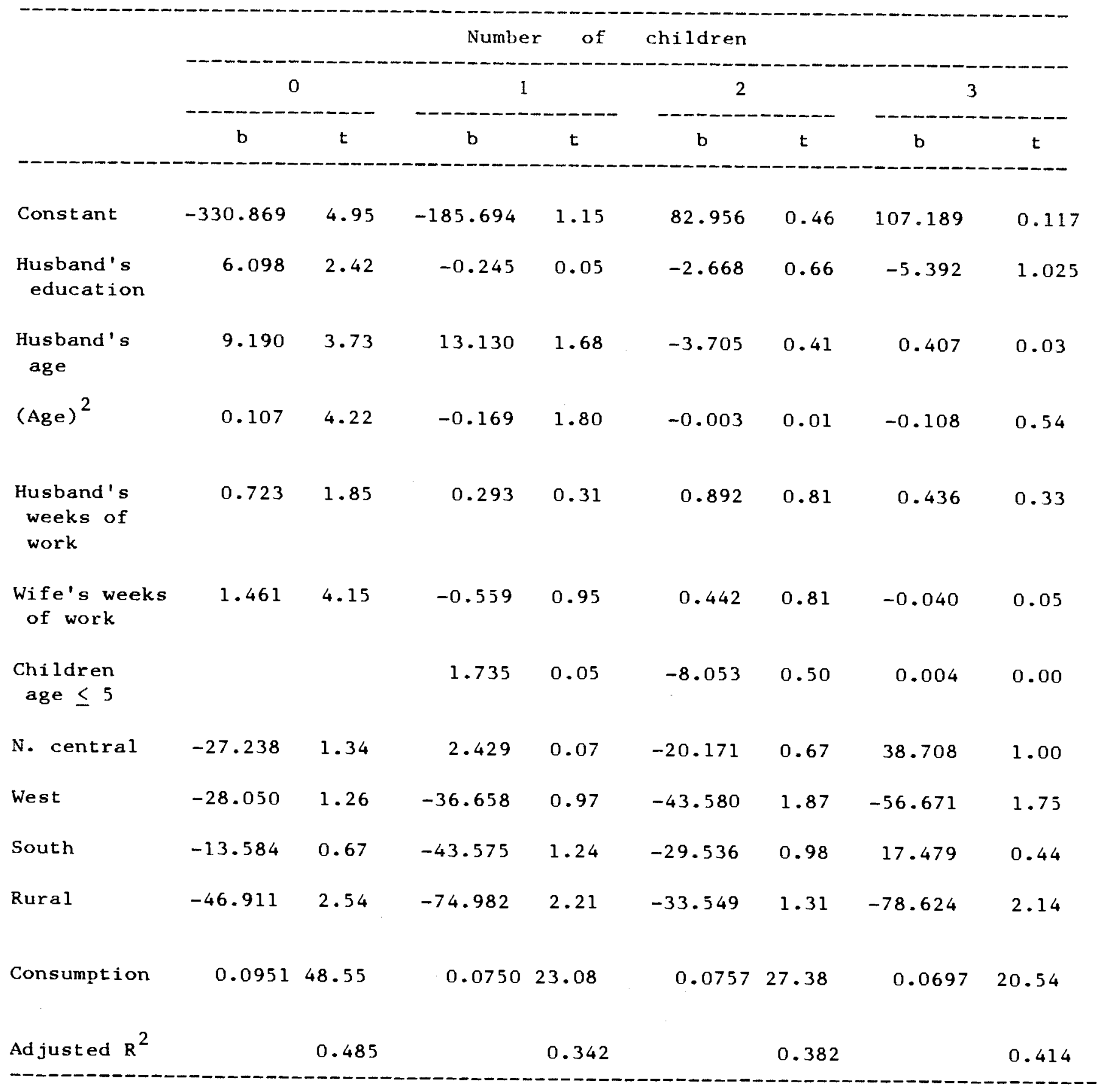




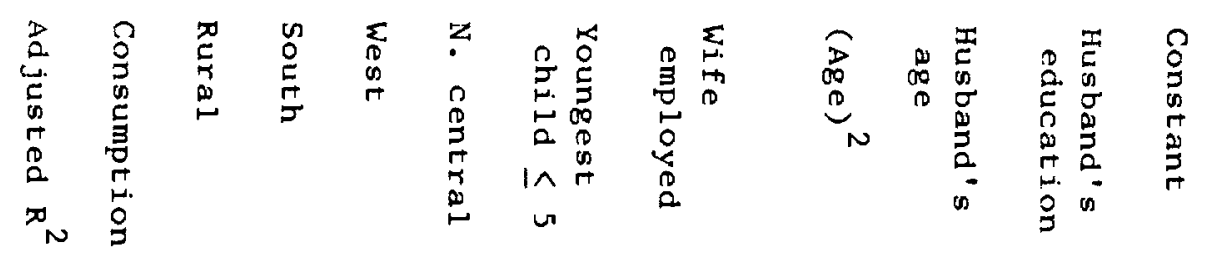

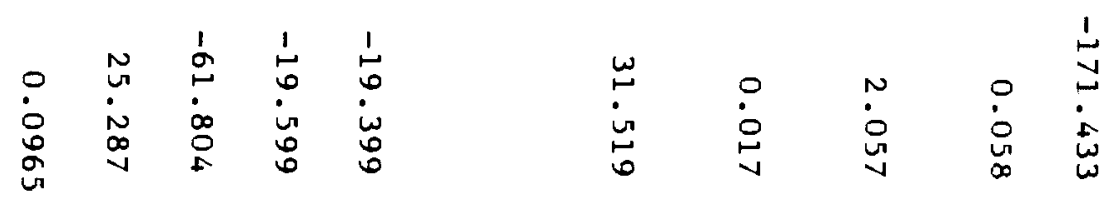

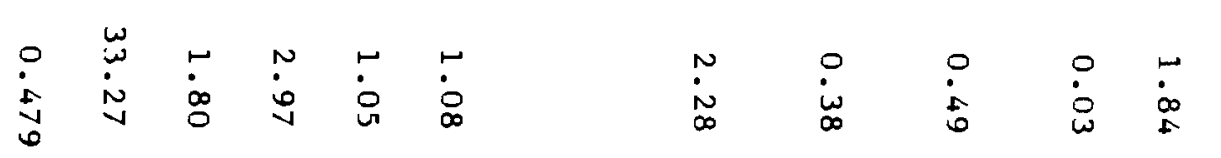

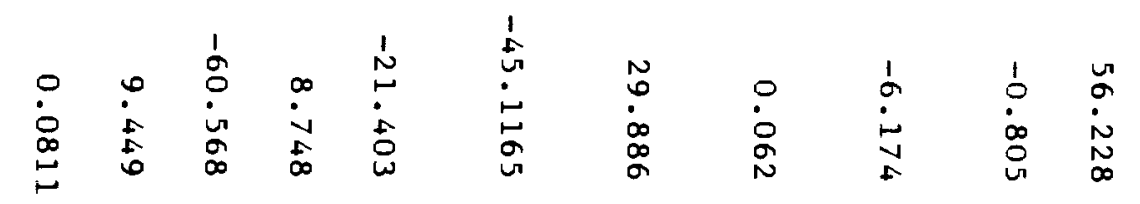

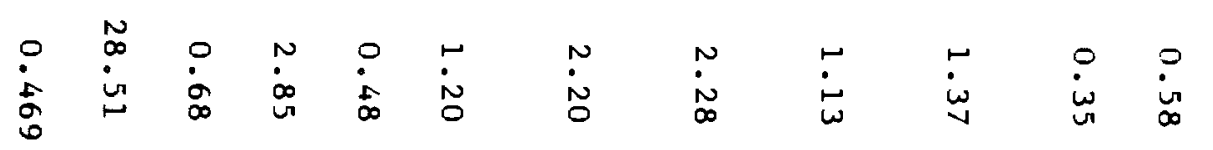

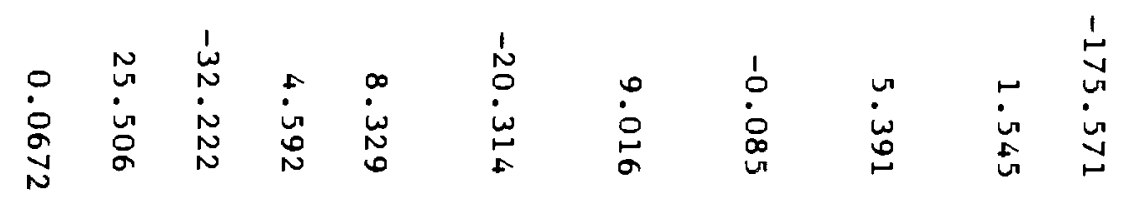

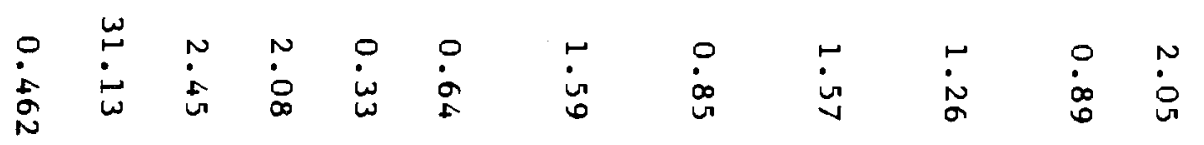

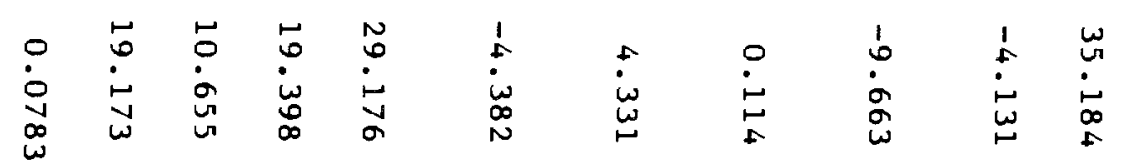

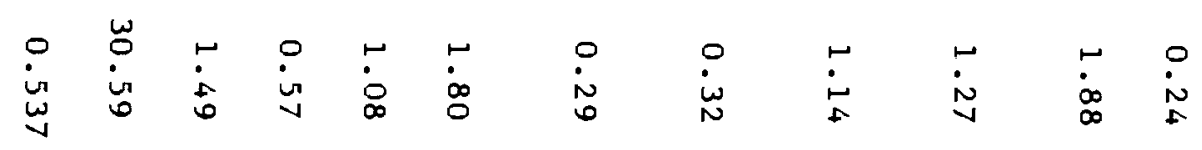

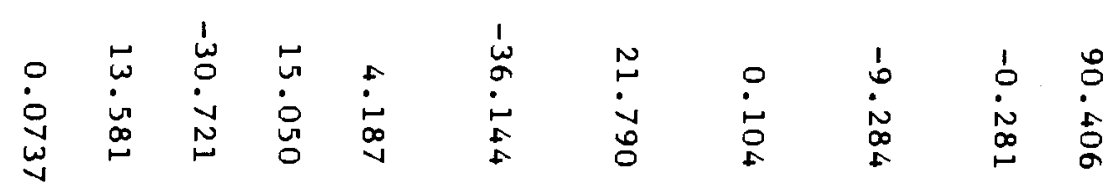

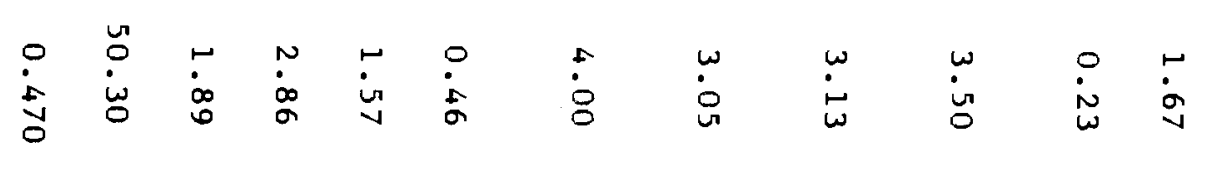

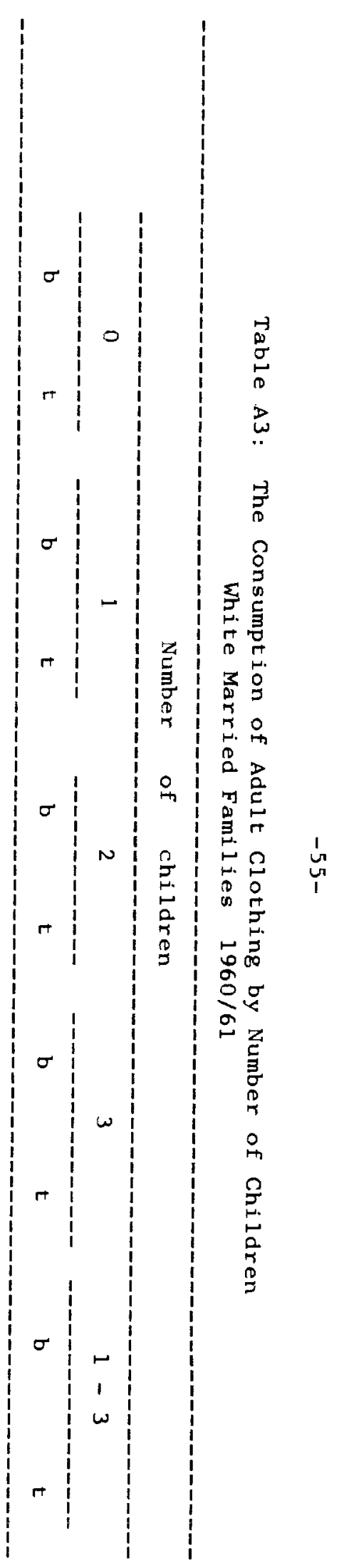




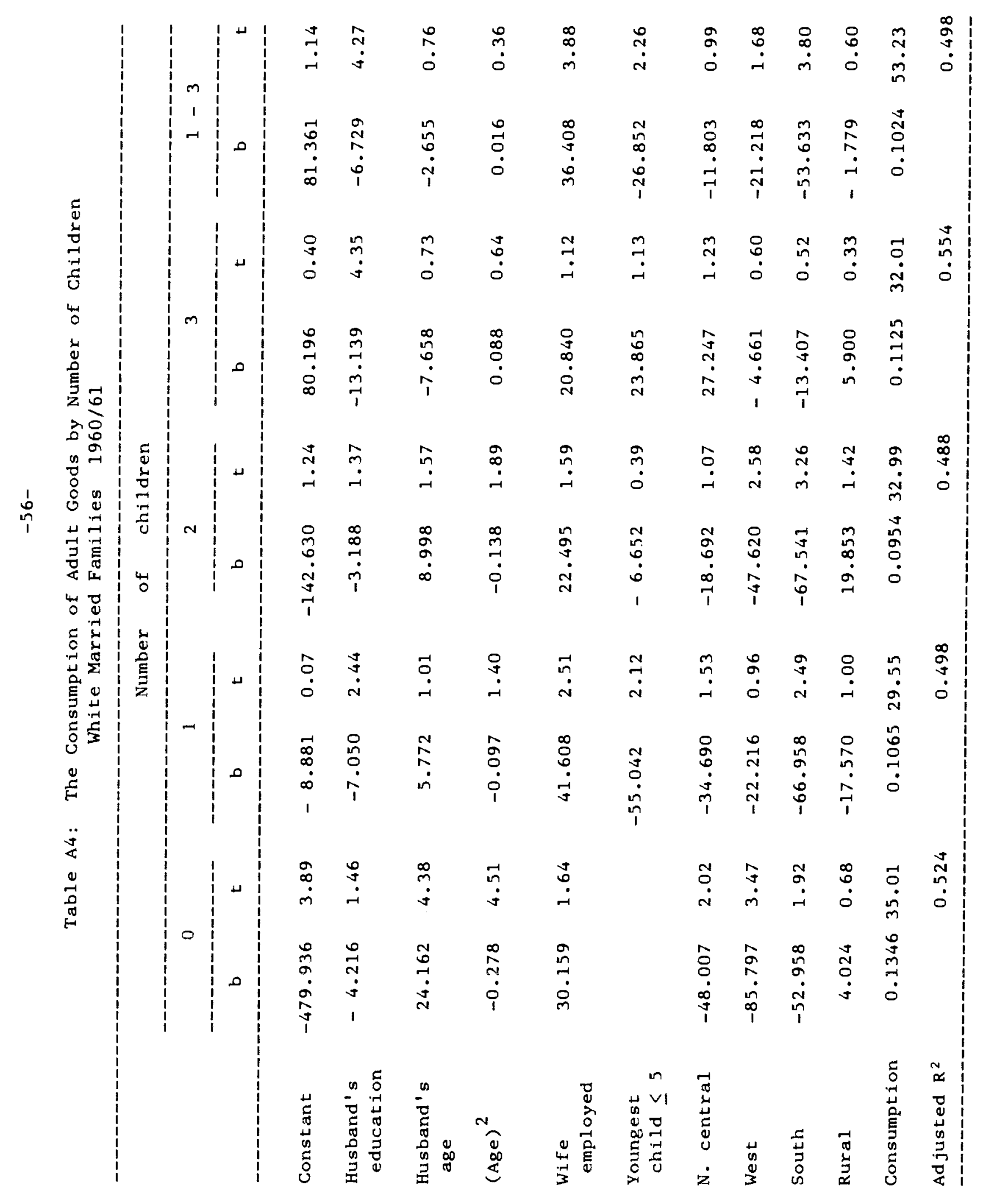


Figure 1

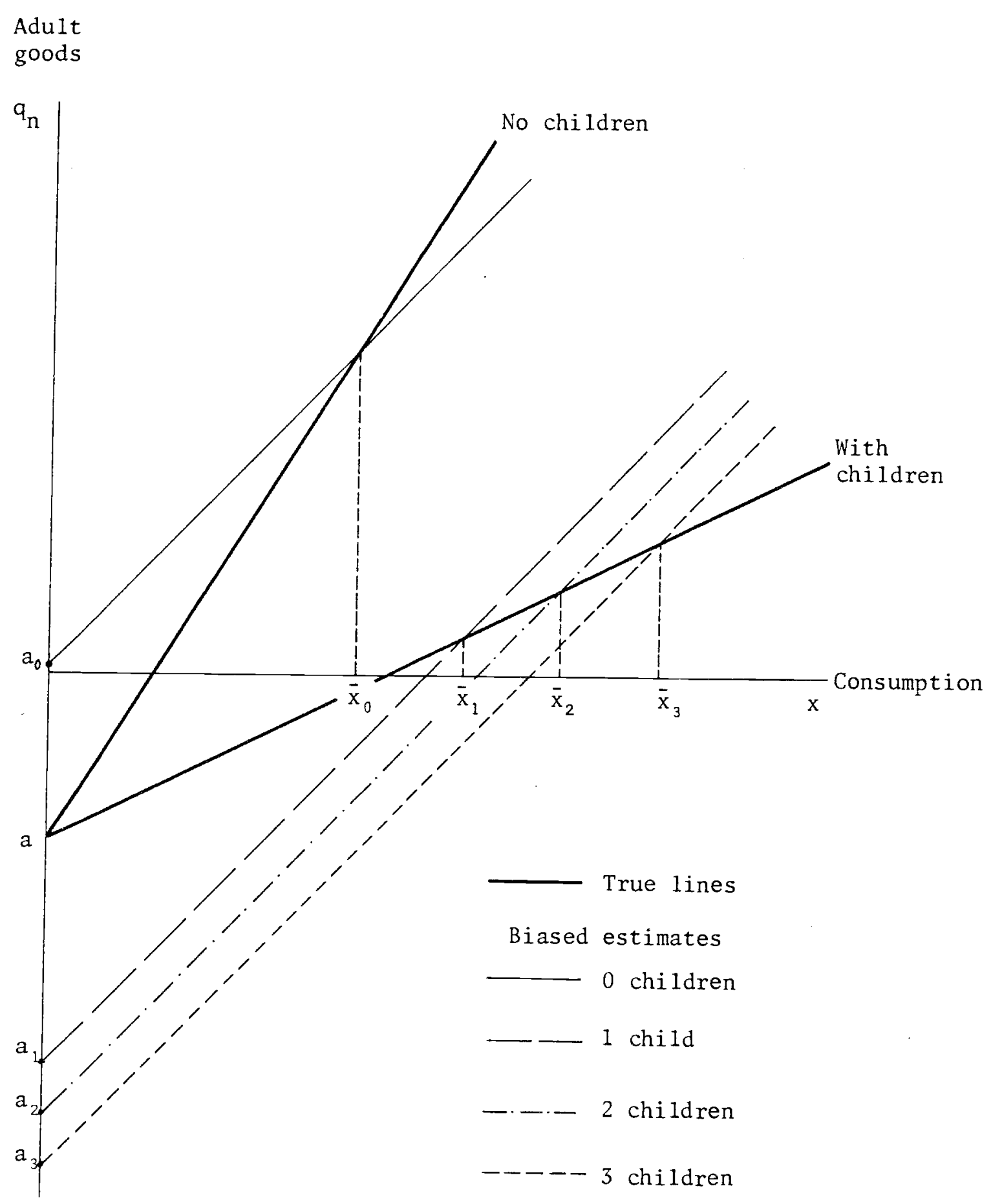

